International Journal of

Environmental Research and

Public Health

ISSN 1660-4601

www.mdpi.com/journal/ijerph

Article

\title{
MicroRNAs in Breastmilk and the Lactating Breast: Potential Immunoprotectors and Developmental Regulators for the Infant and the Mother
}

\author{
Mohammed Alsaweed ${ }^{1,2}$, Peter E. Hartmann ${ }^{1}$, Donna T. Geddes ${ }^{1}$ and Foteini Kakulas ${ }^{1, *}$ \\ 1 School of Chemistry and Biochemistry, The University of Western Australia, Crawley 6009, \\ Western Australia, Australia; E-Mails: mohammed.alsaweed@research.uwa.edu.au (M.A.); \\ peter.hartmann@uwa.edu.au (P.E.H.); donna.geddes@uwa.edu.au (D.T.G.) \\ 2 College of Applied Medical Sciences, Majmaah University, Almajmaah, Riyadh 11952 , \\ Saudi Arabia
}

* Author to whom correspondence should be addressed; E-Mail: foteini.kakulas@uwa.edu.au; Tel.: +61-864-884-467.

Academic Editors: Jane Scott and Colin Binns

Received: 30 September 2015 / Accepted: 27 October 2015 / Published: 30 October 2015

Abstract: Human milk (HM) is the optimal source of nutrition, protection and
developmental programming for infants. It is species-specific and consists of various
bioactive components, including microRNAs, small non-coding RNAs regulating gene
expression at the post-transcriptional level. microRNAs are both intra- and extra-cellular and
are present in body fluids of humans and animals. Of these body fluids, HM appears to be
one of the richest sources of microRNA, which are highly conserved in its different fractions,
with milk cells containing more microRNAs than milk lipids, followed by skim milk.
Potential effects of exogenous food-derived microRNAs on gene expression have been
demonstrated, together with the stability of milk-derived microRNAs in the gastrointestinal
tract. Taken together, these strongly support the notion that milk microRNAs enter the
systemic circulation of the HM fed infant and exert tissue-specific immunoprotective and
developmental functions. This has initiated intensive research on the origin, fate and
functional significance of milk microRNAs. Importantly, recent studies have provided
evidence of endogenous synthesis of HM microRNA within the human lactating mammary
epithelium. These findings will now form the basis for investigations of the role of 
microRNA in the epigenetic control of normal and aberrant mammary development, and particularly lactation performance.

Keywords: human milk; breastmilk; breastfeeding; RNA; microRNA; cells; lipids; skim milk; immune system; development; infant formula

\section{Introduction}

Since their recent discovery in 1993, microRNAs (also known as miRNAs) have emerged as key regulators of gene expression at the post-transcriptional level in humans, animals and plants [1,2]. They act by binding to an mRNA target to either inhibit the translation of mRNA into protein and/or promote its degradation [3-5]. The microRNA family includes extremely small non-coding RNA ( 22 nucleotide in length) that have been isolated from cells, tissues and body fluids of various mammalian species [6,7]. The biogenesis of microRNA comprises three main processes [8]: microRNAs are first transcribed into primary microRNA (pri-microRNA) from specific independent genes on DNA by RNA polymerase II, and are then converted into hairpin precursor microRNA (pre-microRNA) by the Drosha-DGCR8 complex. The enzyme Dicer then produces mature microRNA from pre-microRNA in the cytoplasm (Figure 1) [7,9]. According to miRBase version 21.0 (http://www.mirbase.org) released in June 2014, the number of pre-microRNAs in the human is estimated to be 1881 . These correspond to 2588 known mature microRNAs, while the number of human protein-coding genes that are considered to be targets of microRNAs is estimated to be approximately 20,000-25,000 [10]. Therefore, a single mature microRNA can bind and regulate multiple mRNAs (genes) [6]. Importantly, ongoing research is still discovering new microRNAs.

In mammalian cells, various functional studies have demonstrated that microRNAs regulate up to $50 \%$ of protein synthesis (gene expression) [4]. Several roles of different microRNAs were investigated experimentally and they are involved in regulating a range of biological processes in plants and mammals (including humans) [3,11,12]. In addition to controlling normal physiological processes, microRNAs have been implicated in pathologies such as cancer, autoimmune diseases, gastrointestinal diseases, and diseases of the reproductive system $[3,4]$. microRNAs have recently been reported to be important regulators of pluripotency-related genes and they have been used to reprogram somatic cells into induced pluripotent stem cells (iPSCs) [13-15]. This regulation could potentially be an important method for regenerative medicine and biomedical research, as it eliminates the need for viral vectors. Viral vectors are used to reprogram cells into iPSCs, however they have been shown to uncontrollably influence reprogramming via random insertion of exogenous sequences into the genome [16,17].

Further to their role in the epigenetic regulation of stem cell fate and function, microRNAs also regulate the mammalian immune system. Their functions include regulation of $\mathrm{T}$ and $\mathrm{B}$ cell development [18,19], release of inflammatory mediators [20], proliferation of neutrophils and monocytes [21], and differentiation of dendritic cells and macrophages [22]. microRNAs are also thought to be involved in haematopoiesis [23], cardiac muscle development [24], insulin secretion [25], and neurogenesis [26]. Given their role in numerous physiological processes, deregulation of microRNA function can lead to disease; therefore, increasing evidence supports their use as diagnostic biomarkers. 
Either upregulation or downregulation of microRNAs has been found to be associated with initiation and progression of some types of cancers [27]. These include breast cancer [28], where upregulation of oncogene miR-2 has been shown to be involved in both initiation and progression of the disease [29].

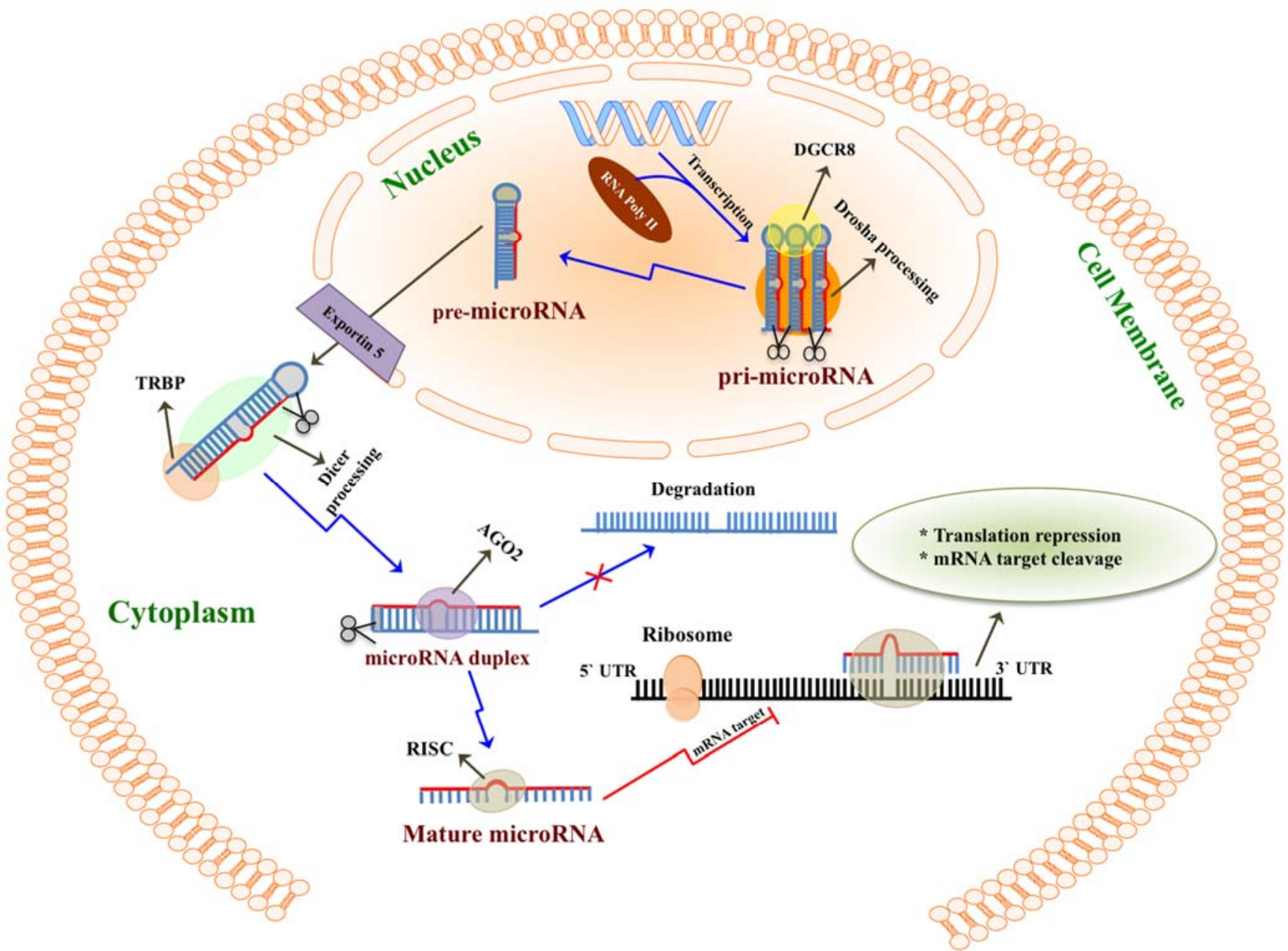

Figure 1. The predicted biogenesis of microRNA. MicroRNA are first transcribed from specific genes on DNA as primary microRNA (pri-microRNA) by RNA polymerase II (RNAPII). In the nucleus, pri-microRNA are converted into $\sim 70$-nucleotide precursor hairpin microRNA (pre-microRNA) by the enzymatic Drosha-DGCR8 complex. Pre-microRNA are then transported from nucleus to the cytoplasm by Exportin 5. There, the Dicer-TRBP complex produces $\sim 20$ base pair $3 \mathrm{~s}^{\prime}$ microRNA and $5^{\prime}$ microRNA duplex. Dicer with assistance from argonaute 2 (AGO2) generates mature microRNA by cleaving the double strand of pre-microRNA. Only one strand of microRNA ( $3^{\prime}$ microRNA or 5' microRNA) can be attached into the RNA-induced silencing complex (RISC). Finally, the microRNA/RISC complex binds into specific mRNA during protein translation, recognizing their target via a 6-8 nucleotides match-mir process (seed region). This results in either repression of the mRNA translation into protein or mRNA degradation.

High levels of microRNAs have been detected in body fluids, such as plasma, urine, saliva, seminal fluid, tears, cerebrospinal fluid (CSF) and more recently, milk [30]. Milk is a non-invasive source of numerous biomolecules that are either synthesized in the lactating breast or are transferred via the 
systemic circulation and provide important functions for both the lactating mother and the breastfed infant. To a large extent, milk microRNAs appear to be endogenous to the mammary gland [31] and could therefore be employed as biomarkers for both the performance and health status of the gland during lactation, and its aberrant growth associated with breast cancer. Further, food-derived microRNAs (e.g., exogenous miR-168a) [32] have been suggested to survive the mammalian gastrointestinal (GI) tract and regulate mammalian genes [32,33,34]. As human milk (HM, breastmilk) is highly enriched in microRNAs, it would be of great interest to illuminate the fate and function of this breastmilk component in the infant during breastfeeding and any long-term effects conferred during this period. Interestingly, bovine milk microRNAs miR-29b and miR-200c, which are also present in HM [35,36], have been shown to survive the GI tract of adult humans and increase in their serum post-consumption [37]. More recently, bovine milk exosomal microRNA transfer was demonstrated in human intestinal colon cells and rat small intestinal cells by endocytosis in vitro [38], further highlighting the important role of vehicle-mediated transfer of milk microRNA [39].

\section{MicroRNAs Are Highly Enriched in Milk}

\section{1. microRNAs in Mammalian Milk}

HM is considered the optimal food for term infants in the first six months of life [40], with the World Health Organization recommending exclusive breastfeeding for up to six months, with continuation of breastfeeding for at least the first two years [41]. In addition to providing nutrition, HM has long been known to protect the infant from infections and to play developmental functions integral to the infant, in which microRNAs are likely to be highly involved. microRNAs can be isolated and experimentally studied in the main three fractions of milk, the cells, lipids, and skim milk (Figure 2). Interestingly, HM is one of the richest microRNA source of all body fluids in the human, containing up to $\sim 1400$ mature microRNAs (Figure 3) [35,36,42,43,44,45,46]. Cellular and lipid fractions of HM contain a greater amount of microRNAs compared to the skim milk fraction [44,47], which is important to consider when analyzing milk microRNA. Not surprisingly, a wide variation in microRNA expression amongst lactating women has also been shown [48], with the factors that influence this variation having not been studied to date. Further, animal studies have shown that the type and expression levels of microRNA are distinctly different between the lactating and non-lactating mammary glands in the cow [49]. microRNAs were also found to be in involved in mammary gland development in murine models [50]. These animal studies have suggested a key role of microRNAs in the regulation of the development and performance of the lactating mammary gland, and they therefore have the potential to influence milk synthesis.

\section{2. microRNAs in Different Milk Fractions}

In 2010, Weber et al. isolated and profiled microRNA from 12 different human body fluids, including human colostrum and milk [30]. In the same year, microRNAs were profiled in skimmed HM [48]. Since then, a few studies have profiled microRNA in HM and in the milk of other mammalian species (Table 1) $[36,44,48]$. This was carried out using different platforms including qPCR, microarray analysis and small RNA sequencing [30,36,44,48,51,52]. Although qPCR is generally the method of choice 
providing high sensitivity and specificity, with low RNA input requirements, small RNA sequencing is often employed to screen for all microRNAs present. This allows identification of novel microRNAs and it is sensitive enough for microRNA quantification. Small RNA sequencing is done either using high throughput next generation sequencing (NGS) or small-scale NGS platforms [4].

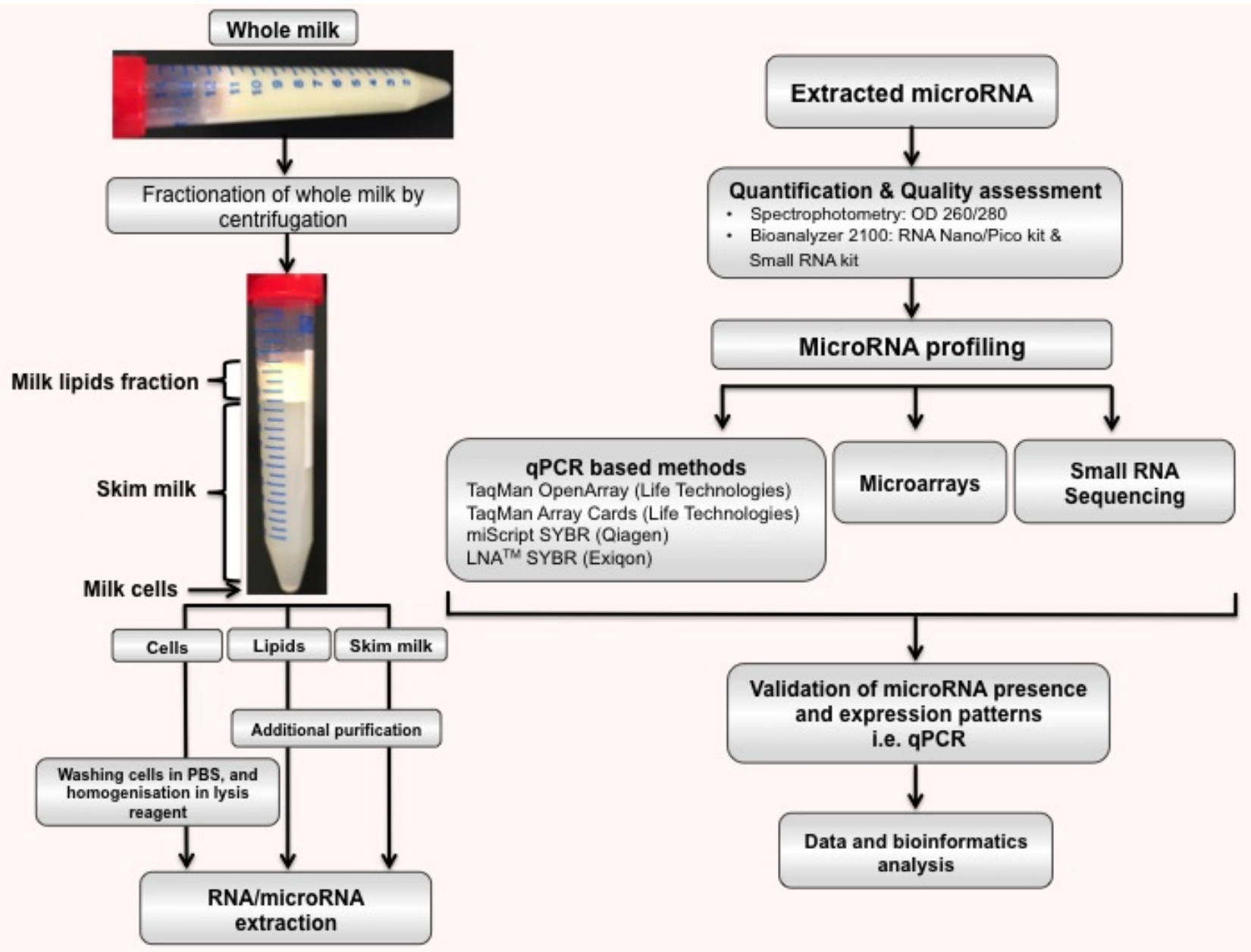

Figure 2. A workflow of microRNA identification in HM. Whole HM can be fractionated by centrifugation for $20 \mathrm{~min}$ at $800 \mathrm{~g}$ at $20{ }^{\circ} \mathrm{C}$ to obtain three fractions including the cells, the lipid layer and skim milk. Total RNA and microRNA can be extracted from each fraction using the optimal kit [47]. Profiling of microRNA after quantification and measurement of its quality can be performed using three different methods [47]: phenol/guanidine, filter column, and a combination of the filter column and phenol/guanidine methods. Small RNA sequencing can determine novel microRNAs and identify all microRNAs in a sample. Microarray analysis and qPCR-based methods can on principle only measure specific microRNAs. Validation of presence and expression patterns of a microRNA of interest is done using qPCR as it is highly sensitive and specific. 

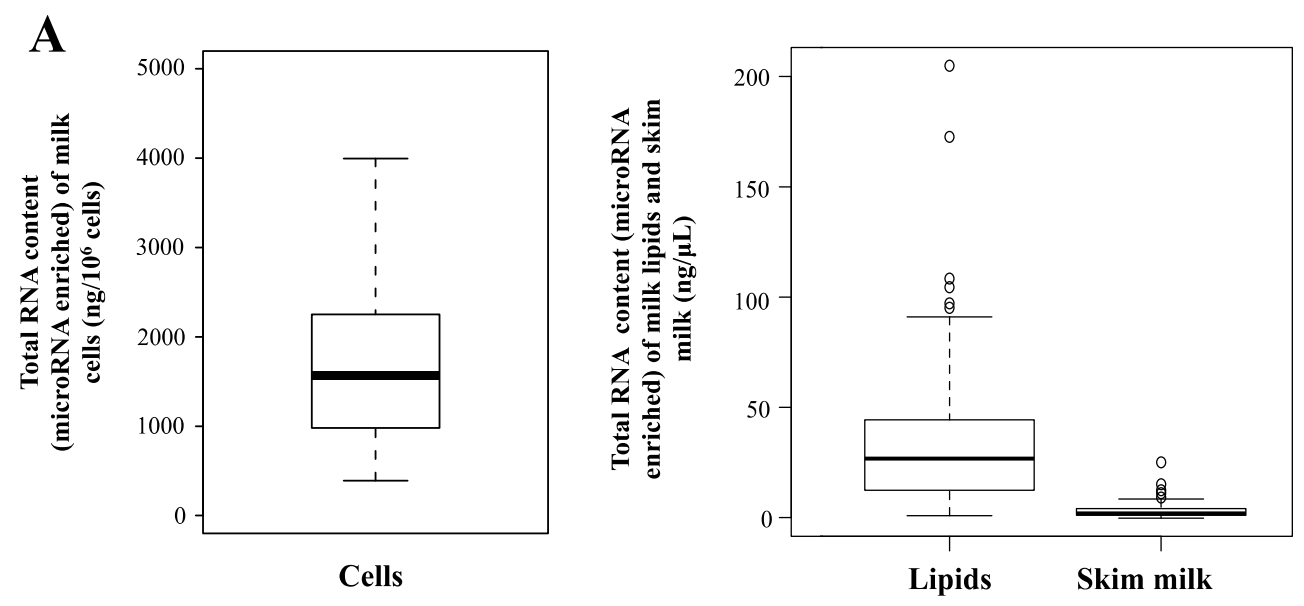

B

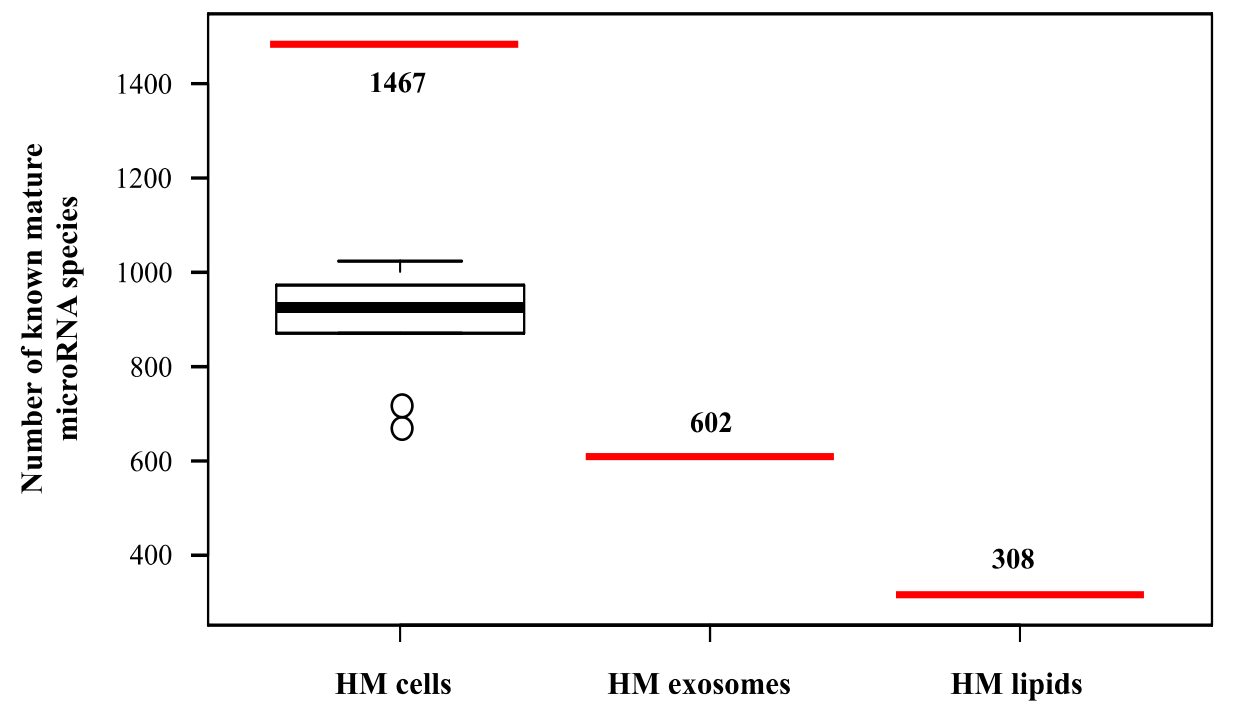

Figure 3. Differences in the microRNA content between the different fractions of human milk. (A) Box plots showing the total RNA content (enriched in microRNA) measured using NanoDrop 2000 in HM cells ( $n=30$ milk samples from 20 mothers), lipids $(n=127$ milk samples from 79 mothers) and skim milk ( $n=116$ milk samples from 79 mothers) obtained from healthy breastfeeding mothers $[35,45,47]$. (B) Box plot showing the number of mature microRNA species that have been identified in HM cells, lipids and exosomes using deep small RNA sequencing. HM cell microRNAs were profiled in $n=20$ samples collected from 10 healthy exclusively breastfeeding mothers in month 2 of lactation [35] using Illumina HiSeq2000, with total clean reads of 268,681,616 matched to miRBase version 20.0. This study identified 1467 different mature known microRNAs in HM cells. HM lipid samples $(n=7)$ were sequenced using an Illumina $1 \mathrm{G}$ Genome analyzer, with 124,110,646 clean reads mapped to miRBase version 16.0. This study identified 308 mature known microRNAs in HM lipids [44]. HM exosome samples $(n=4)$ were sequenced using an Illumina Genome analyzer II, with $83,520,000$ clean reads matched to miRBase version 17.0. This study identified 602 mature known microRNAs in HM exosomes [36]. 
Amongst the 12 human body fluids analysed, Weber et al. used qPCR to profile 429 known mature microRNAs in mature skimmed HM and 386 known mature microRNAs in skimmed human colostrum (the mammary secretion produced in the first few days postpartum) [30]. This study demonstrated for the first time the high abundance of microRNA in HM, which is in accordance with its high total RNA content compared to other body fluids $(47,240 \mu \mathrm{g} / \mathrm{L}$ vs. $308 \mu \mathrm{g} / \mathrm{L}$ in plasma and $94 \mu \mathrm{g} / \mathrm{L}$ in urine) [30]. Microarrays were first used to profile microRNAs in HM by Kosaka et al., who examined 281 different microRNAs in skimmed HM obtained in the first six months of lactation [48]. Although these two pioneering studies focused on microRNA analysis in skimmed HM, it has been argued that the other two main milk fractions (lipids and cells) are likely to harbor large quantities of microRNAs. Indeed, later Munch et al. analyzed the lipid fraction of HM using small RNA sequencing and found high quantities of microRNA, reporting 308 microRNA species that are predicted to target a total of 9074 genes [44]. In addition, a subsequent study performed deep sequencing to profile microRNAs from $\mathrm{HM}$ exosomes [36], which are small cell-derived vesicles carrying proteins and molecules present in all body fluids [53]. This study found 639 exosomal mature microRNAs originating from 452 pre-microRNAs [36].

Table 1. Number of mature known microRNA species reported for different mammalian species for the three milk fractions (cells, lipids and skim milk).

\begin{tabular}{lllll}
\hline Species & Milk Fraction & microRNAs & Profiling Method & Reference \\
\hline \multirow{6}{*}{ Human } & Skim milk (mature) & 429 & qPCR & {$[30]$} \\
& Skim milk (colostrum) & 386 & qPCR & {$[30]$} \\
& Skim milk (mature) & 281 & Microarray & {$[48]$} \\
& Milk exosomes & $639 * *$ & Solexa deep sequencing & {$[36]$} \\
& Milk lipids & 308 & Solexa deep sequencing & {$[44]$} \\
& Milk cells & $450 * * *$ & TaqMan OpenArray & {$[45,46]$} \\
& Milk lipids & $337 * * *$ & TaqMan OpenArray & {$[45,46]$} \\
& Milk cell pre-feed & 1287 & Solexa deep sequencing & {$[35]$} \\
& Milk cell post-feed & 1308 & Solexa deep sequencing & {$[35]$} \\
\hline \multirow{5}{*}{ Bovine } & Skim milk (colostrum) & 230 & Solexa deep sequencing & {$[52]$} \\
& Skim milk (mature) & 213 & Solexa deep sequencing & {$[52]$} \\
& Skim milk (colostrum) & 100 & Microarray & {$[54]$} \\
& Skim milk (mature) & 53 & Microarray & {$[54]$} \\
\hline \multirow{2}{*}{ Porcine } & Milk exosomes & $180 * *$ & Solexa deep sequencing & {$[51]$} \\
& Milk exosomes (colostrum) & 491 & Solexa deep sequencing & {$[55]$} \\
\hline \multirow{2}{*}{ Murine (rat) } & Skim milk (colostrum) & 128 & Microarray & {$[56]$} \\
& Skim milk (mature) & 144 & Microarray & {$[56]$} \\
\hline
\end{tabular}

* Number of detectable mature microRNAs; ** Precursor microRNAs (pre-microRNAs); *** $8 \leq \mathrm{Ct} \leq 29$.

More recently, we used the Taqman OpenArray Panel system (Applied Biosystems, Foster City, CA, USA) to screen 754 human mature microRNAs in the cellular and lipid fractions of HM. In addition, we performed comparisons with the microRNA content of maternal peripheral blood mononuclear cells (PBMCs) and plasma [46]. This analysis identified 293 and 233 microRNA species in the breastmilk cell and lipid fractions, receptively. Maternal PBMCs contained 345 different microRNAs, whereas only 169 were found in maternal plasma. Breastmilk cells and PBMCs had significantly higher microRNA content compared to breastmilk lipids and plasma, respectively 
$(p<0.05)$. Correlation and cluster analyses showed that breastmilk cells and lipids were highly related in terms of microRNA expression patterns and species, however PBMC microRNAs were not correlated with breastmilk microRNAs. In plasma, marked inter-individual variation in expression levels of single microRNA species was observed. This study together with our previously published optimization of microRNA extraction from HM [47] demonstrated the presence of microRNAs in all three fractions of HM (cells, lipids, and skim milk), and revealed that HM conserves more microRNAs with different expression patterns compared to maternal plasma [46], but also other human body fluids [30]. Skim milk (known as the plasma phase of milk) is cell and fat globule free milk, and appeared to be extremely low in microRNAs and total RNAs compared to the cell and lipid milk fractions [47].

In addition to HM, microRNA have been analyzed in other mammals' milk, particularly the dairy cow, in various studies (Table 1) [51,52,53,54]. Mature bovine skim milk has been shown to contain 213 microRNA species using deep sequencing [52] and 53 using microarrays [54]. Some of these microRNA are enriched in either mature milk or colostrum [52]. Specifically, bovine colostrum has been found to be richer in microRNA (both higher total content and species number) compared to mature bovine milk, where 230 and 100 microRNAs were identified in skimmed bovine colostrum in the above studies, respectively (Table 1) [52,54]. Similarly, bovine milk-derived microvesicle RNA and total milk RNA levels have been shown to be higher in colostrum compared to mature milk $[53,54]$. Unlikely bovine milk, skimmed rat colostrum was shown to conserve fewer microRNA species (128) than mature rat skim milk (144) (Table 1) [56]. Izumi et al. [54] isolated 53 mature microRNAs from mature bovine skim milk, and 100 from skimmed bovine colostrum (Table 1). $\mathrm{Gu}$ et al. examined the exosomes of porcine milk using small RNA sequencing at six time points of lactation within the first month postpartum $(0,3,7,14,21$, and 28 days after birth) and found 180 pre-microRNAs encoding 237 mature microRNAs, which are also found in HM (Table 1) [51]. However, 39 pre-microRNA were identified that were not homologues of HM microRNA [51]. This was one of the first efforts to quantify changes in milk microRNA content over time, in this case within the first month of lactation, which can provide insight into both their involvement in the maturation of the mammary gland into an organ that synthesizes copious amounts of milk and their role(s) in the development and protection of the offspring. Another study in porcine milk exosomes identified 491 mature microRNAs by small RNA sequencing in the first 6 days postpartum (Table 1) [55]. These pre-microRNA that are shared between different species potentially have similar physio-pathological mechanisms of action and functions in milk amongst mammals [51]. In all animal milk microRNA studies to date, only a few microRNA were found to be highly expressed [30,36,44,48,51,52]. For example, the top 10 most highly expressed microRNAs in exosomal porcine milk were contributing approximately $87 \%$ of the total 234 microRNA [51].

\subsection{Origin of Milk microRNAs}

Our comparisons between breastmilk blood microRNA provided important insight into the origin of milk microRNA, with the mammary gland appearing to be the main source of milk microRNA, with the maternal circulation having a smaller contribution [46]. This was consistent with a recent microRNA analysis in tammar wallaby milk. In the tammar study, most microRNAs were differentially expressed between skim milk and blood serum, although the total number of microRNA species was 
similar in both milk and serum (86 and 82 microRNAs, respectively) [57]. Prior to these findings, it was believed that because ribosomal RNA (18S and 28S) measured by the Bioanalyzer is usually absent or low during the isolation and quantification of microRNA, microRNA are less likely to be secreted from milk cells [51,54]. Nevertheless, taken together, the similarities between milk cell and lipid microRNAs, the differences with PBMCs and plasma both in the human [45] and dairy cow [52], and the known secretion of milk lipids from lactocytes, which are the most abundant cell type in HM under healthy conditions [58], strongly suggest that the milk cell and lipid microRNAs are primarily endogenously synthesized in the mammary gland [45,57]. Moving forward, it will be important to understand the factors controlling mammary microRNA synthesis during pregnancy and lactation, as this is likely to impact the health and development of both the mammary gland and the infant.

\subsection{Milk microRNAs as Diagnostic Tools}

Although the microRNA content and composition of different milk fractions is being intensively investigated, the understanding of factors influencing them as well as the roles and functions of these molecules in the lactating mammary gland and for the breastfed offspring is still very poor. A number of maternal and/or infant characteristics have previously been reported to influence the composition of HM, including infant feeding, preterm birth, the stage of lactation, parity, maternal body mass index (BMI), infant sex, and the health status of the mother and the infant [59-65]. It is not unlikely that some of these factors may affect the microRNA content of HM, yet very few studies have examined these associations. Recently, the effects of infant feeding and milk removal on HM microRNA content and composition were investigated $[45,46]$. It is well established that post-feed milk contains more fat and cells compared to pre-feed milk [60,61]. Similarly, additional microRNA species were detected in postfeed milk, however the difference in the total number of microRNA species or the expression of the majority of microRNAs between pre- and post-feed milk was not statistically significant in a group of 10 lactating women examined in month 2 of lactation $(n=10, p>0.05)$. Yet, a subgroup of 27 known and 1 novel microRNAs in this study were expressed more highly post-feeding $(p<0.05)$. From these findings, it can be concluded that milk removal may influence the content and/or expression of certain microRNAs in HM, but the overall microRNA composition appears to remain constant [35]. This is in agreement with Kosaka et al., who showed variable microRNA expression patterns between mothers, but claimed no significant intra-individual variation in microRNA expression [48]. Yet, this study only collected 2-4 samples from each of eight lactating women at different stages of lactation without standardizing the sampling based on infant feeding/milk removal or time of the day. Therefore, further studies are required to shed light into factors that may influence HM microRNA content within a mother. Nevertheless, Kosaka et al. [48] as well as the more recent study by Alsaweed et al. [35] showed great inter-individual variation in HM microRNA content, which could potentially be associated with parity, preterm birth, infant characteristics or environmental factors (e.g., maternal diet) [37,66]. Interestingly, maternal diet has been shown to influence other HM components, such as fatty acids [67] during lactation, but also fetal growth and health during pregnancy $[68,69]$. 
Similarly to numerous other immunological components of HM (immune cells, lysozyme, lactoferrin, immunoglobulins [62,70]), immune-related milk microRNA may be influenced by the health status of the mother and/or the infant. Although this has not been investigated in HM, a recent study in the dairy cow examined milk from healthy cows and those infected with S. uberis 0140J. It was found that 26 microRNAs isolated from milk cells described as monocytes were differentially expressed between the two cohorts [71]. The majority of the differentially expressed microRNAs are implicated in innate immunity, suggesting that infection of the lactating breast changes the milk microRNA profile to enhance immunoprotection and facilitate recovery. It is of note that in this study, milk monocytes were identified using the marker CD14, which is also expressed by milk epithelial cells [58,70]. Although epithelial cells are not the dominant cell type in bovine milk, in contrast to HM [58,70], the microRNA profiles reported in this study are likely to represent more cell types than just monocytic immune cells of milk.

Although in HM the effects of infection on microRNA profiles are currently under investigation, evidence from animal studies supports the use of milk microRNA as a tool of assessing the health status of the lactating breast as well as the response to treatment, similarly to what has been previously shown for breastmilk immune cells $[62,70]$. The potential diagnostic value of milk microRNA has also been suggested by other animal studies. miR-148a-3p, which has been found to be the most highly expressed microRNA in exosomes of HM [36], bovine [52] and porcine milk [51], has been proposed as a biomarker for raw milk quality control in the dairy industry, and also for artificial infant formulae [52]. The use of microRNAs as biomarkers for milk quality control was first proposed by Chen et al. due to their high stability in milk, even under very harsh conditions including the sterilizing process during product manufacture and milk processing [52]. However, Weber et al. [30] reported a lower concentration of miR-148a in skimmed HM than what was previously shown in bovine skimmed milk by Chen et al., in HM exosomes by Zhou et al., and in porcine milk exosomes by Gu et al. [36,51,52]. In addition to miR-148-3p, controversies exist over miR-494, which has been identified to be present in high concentrations in both HM [48] and bovine milk by Izumi et al. [54], but in very low concentrations in bovine milk by Chen et al. [52]. It is not clear the degree to which inter- and intra-species variations and factors associated with them have contributed to these differences. Further, differing methodological approaches and lack of standardization of milk collection, storage, processing, milk fractionation (if any), and RNA extraction are also likely sources of potential variation in results. Due to the rapidly evolving techniques in this field, the need is arising for greater emphasis of studies to optimize and standardize the methodology employed in milk microRNA research. These procedures had already been optimized for microRNA extraction and analysis in blood and plasma [72], and only recently this has been done for HM [47].

The optimization of microRNA and total RNA extraction from HM was conducted in three main milk fractions (cell, lipids and skim milk) using different extraction methods and commercially available kits. The most efficient kits and methods were reported for each HM fraction [47]. In this study, microRNAs were found to be enriched in HM, with different milk fractions yielding different microRNA concentrations [45]. Therefore, it became clear that different fractions of HM require different processing for extraction, profiling and functional studies. Importantly, milk samples were fractionated and analysed fresh upon expression and not after storage, enabling extraction and analysis of microRNA specific to each milk fraction. Previous studies on skim milk or milk lipids have typically analysed milk 
after freezing [36,48,51], a process that is likely to result in cross-contamination between milk fractions due to membrane lysis (in milk cells and potentially fat globules) that is known to occur during freezing. These are important considerations for future investigations, with this optimization study now providing a standard protocol for HM microRNA analysis [47].

Furthermore, the optimisation and standardization of the methodology for milk microRNA analyses [47] opens new avenues for clinical exploitation of these molecules diagnostically, particularly given their non-invasive access via breastmilk. The suggested origin of many milk microRNA from the mammary gland $[45,57]$ makes them an attractive target as biomarkers of the health status and performance of the lactating breast as well as of breast aberrations such as cancer. Epigenetic modification has been suggested to be involved in the normal development of the mammary gland, although the specific mechanisms are still largely unexplored [73]. For example, miR-29s was found to regulate important lactation-related genes in mammary epithelial cells from the dairy cow, such as casein alpha S1 (CSN1S1), E74-like factor 5 (ElF5), and glucose transporter 1 (GLUT1) [52,74]. Decreasing expression of miR-29s was associated with reduction of lactoprotein, triglycerides (TG) and lactose [52,74]. These findings can form the basis for examination of potential avenues for enhancement and optimisation of milk quality in the dairy cow, as well as improvement of lactation performance in women with insufficient milk supply.

\section{Functions of Milk microRNAs}

\subsection{Stability and Uptake of Food-Derived microRNAs}

Accumulating evidence confirms that microRNAs are present in all food sources. A number of studies have begun to investigate the fate of food-derived microRNAs, and whether they survive the GI tract and influence gene expression in mammals, including humans [32,33,34,37]. Food-specific microRNAs ingested orally have been found to be present in tissues and sera of different animals. Specifically, exogenous miR-168a, which is a rice-specific microRNA, was present in human sera in a Chinese cohort [32]. miR-168a was found to bind low-density lipoprotein receptor adapter protein 1 (LDLRAP1) in the human and mouse and to inhibit LDLRAP1 expression in the liver [32], demonstrating not only survival and uptake of this food-derived microRNA in humans, but also epigenetic regulation influencing tissue function. However, not all cross-microRNAs from food sources increase after consumption in mammals. For example, miR-167a and miR-824 are highly expressed in broccoli. Extensive consumption of broccoli sprouts by healthy humans did not change the expression pattern of either microRNA in the plasma [37]. Moreover, Dickinson et al. investigated exogenous microRNA uptake in mice by feeding them rice-containing chow. This study failed to report gene-targeting functions of the plant-derived microRNA or change in expression levels in the liver or plasma of the animals [75]. The above discrepancies between studies examining plant-derived microRNA transfer to mammals may reflect the lack and/or minimal contribution of exosomal transfer, since very limited evidence currently supports the production of exosome-like structures by plants that can be uptaken by mammalian cells [76]. Indeed, the packaging of microRNA within "transporting vehicles" may play an important role for their transfer and function in the recipient. 
In the case of HM microRNA, it has been suggested that their transfer to the infant's bloodstream is further facilitated by the known packaging of milk microRNA in "vehicle" structures, such as somatic cells, exosomes and other microvesicles, which may be essential for the long-distance transport of microRNA, given that they are surrounded by a lipid bi-layered membrane and are equipped with adherence molecules, both of which facilitate their ordered endosomal transfer via epithelial cells of the intestine [38]. Through these vehicles, milk-derived microRNA are thought to be uptaken by the infant and participate in the epigenetic regulation of various functions including immune protection and development (Figure 4) [34,77]. In particular, recent studies have emphasized the importance of exosomal transfer of milk-derived microRNA. Extracellular vesicles including exosomes were shown to attach to different types of cells by endocytosis and to carry microRNA such as miR-21, which downregulated expression of TGF $\beta$ RII and TPM1 in the recipient cells $[78,79,80]$. Extracellular vesicles were further investigated in commercial bovine milk, and were found to carry immunoregulatory microRNAs. These milk-derived extracellular vesicles were resistant to harsh conditions such as low $\mathrm{pH}$ [39]. Moreover, uptake and functionality, including therapeutic effects, of milk microRNAs has been recently demonstrated both in vitro and in vivo by Arntz et al. [81]. In this study, immune-related microRNAs (miR-30a, miR-223, miR-92a) were highly expressed in bovine milk-derived extracellular vesicles, which were uptaken in vitro by splenocytes and intestinal cells. When orally administered to BALB/c mice with experimental rheumatoid arthritis, these milk-derived extracellular vesicles were uptaken by RAW264.7 macrophages after $1-3 \mathrm{~h}$ as well as by the ileum tissue of the animals after $24 \mathrm{~h}$. After 9 weeks of daily oral administration, arthritis was delayed, with reduction in cartilage depletion and joint inflammation [81].

In addition to exosomal transfer, HM cells may significantly contribute to the transfer of milk-derived microRNA to the infant. It has been recently shown that stem cells and immune cells from milk are transferred to the bloodstream of suckling pups in mice, and from there to different tissues $[82,83]$. Given that the cells of milk are highly rich in microRNA [35,45], this is likely to be an important source of microRNA for neonates in addition to milk exosomes.

microRNAs contained in infant formulae may also, to a small extent, be transferred to the infant's circulation. Baier et al. investigated bovine milk-derived miR-29b and miR-200c in human adults after consuming cow's milk and found that both microRNAs were increased 2-fold in human PBMCs and could potentially alter gene expression [37]. Both microRNAs were also highly expressed in the human plasma after few hours of consuming cow's milk, and returned to the normal baseline expression level after $24 \mathrm{~h}$ of the initial milk consumption [37]. Furthermore, bovine milk exosomes isolated from commercial milk products were shown to be transported into human intestinal colon carcinoma Caco-2 cells and rat primary small intestinal IEC-6 cells by endocytosis in vitro, a process that was influenced by glycoproteins on the surface of host cells [38]. However, differences exist in the microRNA content between bovine milk and infant formula, with the latter lacking exosomes and viable cells, and thus containing much lower microRNA concentrations (approximately 100-fold lower in bovine milk-based formula compared to raw bovine milk and colostrum [52,84]) [45]. Moreover, the non-human origin of formula microRNA and/or the procedures of formula preparation may be associated with altered biological activity of any remaining microRNA in infant formula. 


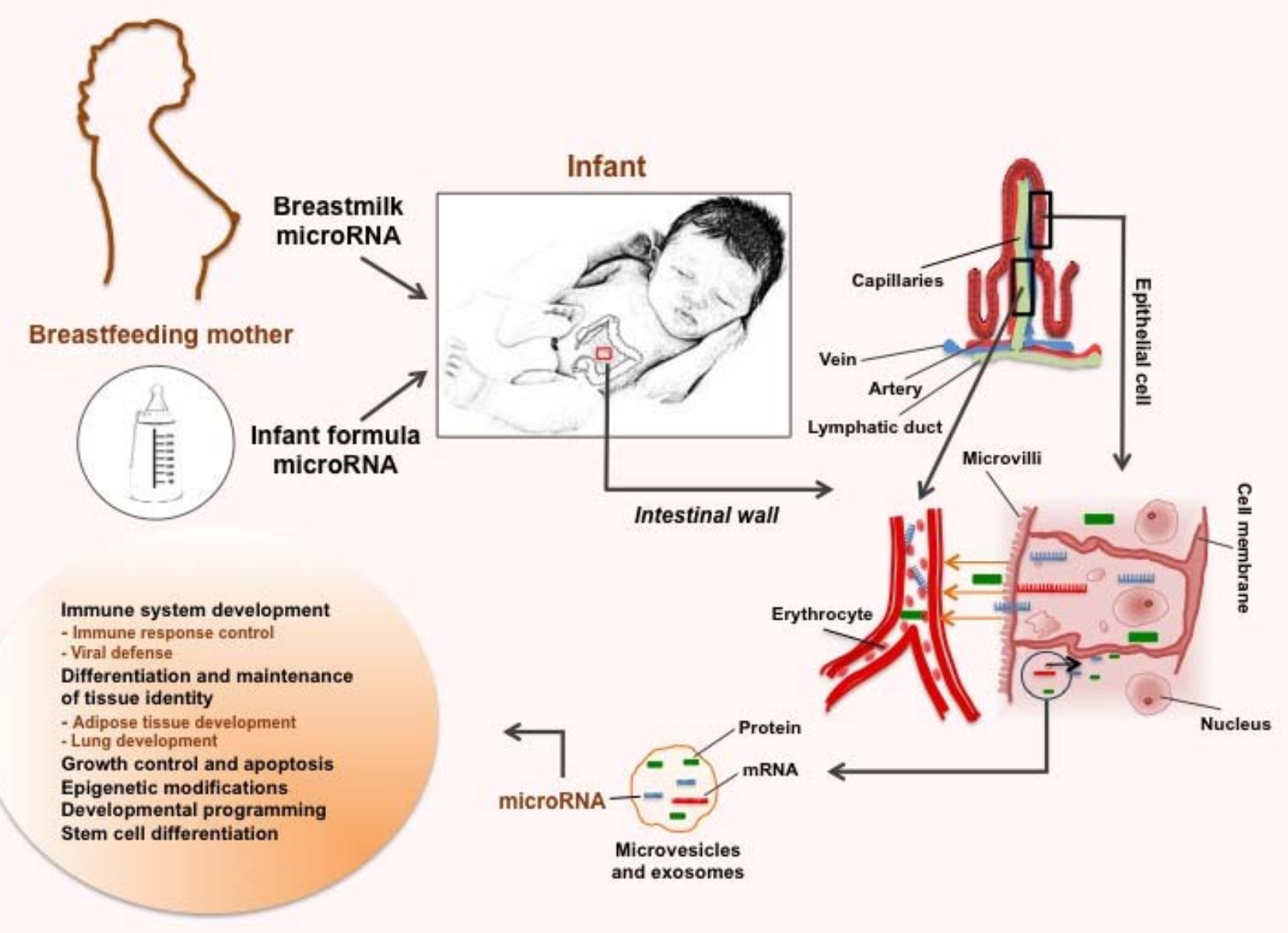

Figure 4. A potential scenario depicting the sources of exogenous microRNA for the infant (breastmilk and infant formulae) and uptake of them along with other macro/micronutrients (i.e., fatty acids and amino acids) in the infant's gastrointestinal (GI) tract. Breastmilk microRNAs can be delivered to the infant either as free molecules in skim milk, or via uptake of breastmilk cells, exosomes and other milk microvesicles in the GI tract. There, absorption is thought to occur through intestinal epithelial cells, from which milk-derived microRNA may reach various organs and tissues via the bloodstream to potentially perform functions, such as immunoprotection and developmental programming. It is of note that infant formulae are extremely poor in microRNA compared to HM, with potential differences also in the biological activity of these molecules in formula that merit further investigation.

One of the major requirements for confirmation of the functionality of food-derived microRNAs in mammals is to demonstrate their survival in the GI tract. Several studies have shown that microRNAs are extremely stable under various harsh conditions in vitro [36,48,85]. For breastmilk microRNA, the main considerations are resistance to RNase digestion and tolerance of low $\mathrm{pH}$, and temperature and freeze/thaw cycles in the case of frozen HM [36,48,53]. Exosomal microRNA has been suggested to be protected [36], but other microvesicles including fat globules are also considered to be involved in microRNA protection, such as apoptotic bodies (small vesicles derived from apoptotic cell death) [48], which have not been investigated yet. Moreover as stated above, milk cellular microRNA may be transferred intact as it 
is protected within cells, which have been shown to survive the GI tract of the offspring and to home in different organs [32,57].

With regard to free microRNA in milk (such as those present in skim milk), a few theories have been proposed. Ribonuclease (RNase), which has been found to exist in all body fluids [86], degrades RNA molecules into small fragments, and is thus a key enzyme in the RNA maturation process [87]. Milk is known to have high RNase activities $[36,48]$. On the other hand, it is known that RNAs are unstable under harsh conditions $[88,89]$. Furthermore, HM and raw milk-derived microRNAs are found to be extremely stable even after RNase treatment in vitro [48,51,53,54]. The effects of low $\mathrm{pH}$ solution on microRNA integrity were examined using qPCR, showing that they are very stable [48,51]. It is important to note that the GI tract of infants is less acidic than that of adults [90], which further supports increased survival of milk microRNA activity. Moreover, milk microRNAs are resistant to milk storage under different temperatures, such as incubation at $100^{\circ} \mathrm{C}$ for $10 \mathrm{~min}$, and freeze-thaw cycles [36,48,51]. As microRNA do not denature if subjected to different temperature cycles (at least those tested), microRNAs in stored HM fed to hospitalized infants are likely to be unaffected [48]. The above observations strongly support the survival of the natural microRNA content of HM in the infant's GI tract, either as free molecules or packaged in vesicles/cells, and thus suggest a potential function of these transferable and stable molecules in the breastfed infant, including the hospitalized infant receiving stored HM.

A recent study utilized a mouse model of miR-375 and miR-200c knockout (KO) pups fed by wildtype (WT) foster mothers or KO mothers [91]. The study concluded that no evidence was found for intestinal uptake in $\mathrm{KO}$ or WT pups of miR-375 and miR-200c derived from foster mother milk [91]. However, a small increase in the plasma levels of both of these microRNAs was detected in KO pups after nursing, suggesting that some microRNA copies are actually transferred to the bloodstream. It is of note that the examined microRNAs were not highly expressed in the WT mother milk of the murine model used. Further, both miR-375 and miR-200c are known to be involved in the control of endocytosis and/or exocytosis and to modulate epithelial function, which may influence exosomal endocytosis and thus uptake of the examined microRNAs [92,93]. Therefore, this KO mouse model and the chosen microRNAs may be inappropriate for investigating milk microRNA uptake by the nursed offspring. As it has been previously shown [37,38], not all dietary microRNAs are ideal for exogenous microRNA uptake studies [94]. Further studies are required to confirm the findings of Title et al. [91] as well as investigate milk microRNA uptake in more appropriate models.

On the other hand, similar to human serum [89], exogenous spiked-in synthesized (artificial) microRNAs in bovine milk were unstable and degraded compared to natural, endogenous microRNAs in bovine milk, which remained stable [51,54]. Interestingly, it is known that HM contains high quantities of very stable microRNAs, which are resistant to the pasteurization and milk bank storage procedures [36,48]. Additionally, microRNAs were found to be active and still regulate their target genes after subjection to ultraviolet radiation (UV-A, UV-B, and UV-C) [95]. In C. elegans, several microRNAs were stably expressed after UV-C treatment, such as miR-57-5p and miR-55-3p [96]. In a study of human primary keratinocytes exposed to UV-A and UV-B for $6 \mathrm{~h}$, most microRNAs survived and no difference in expression was seen, except for few microRNAs such as miR-23b (upregulated) and miR-10a (downregulated) [97]. Yet, other studies have reported upregulation of skin microRNA in response to UV irradiation [98], which may be involved in cancer initiation in the 
skin [99]. In summary, although ultraviolent radiation may not affect the majority of microRNA in mammalian cells, current evidence suggests that some microRNA species may be affected, and therefore this requires further investigation. In general, as it is also emphasized by the food industry and the industry of processing raw milk products such as milk powdechen [52,54], microRNAs in food and milk are very stable under and resistant to harsh conditions, and are therefore likely to be taken up by the HM fed infant, especially when protected within vehicle structures such as exosomes and live milk cells.

\section{2. microRNAs Act as Immune Regulators}

The tolerance of microRNAs of harsh conditions and the evidence that they migrate to the bloodstream and potentially different organs of the breastfed infant, suggest that they may play functional roles in the epigenetic regulation of development. Most of the microRNAs in HM are known for their immunocompetence [54,100,101], and they are particularly abundant (Table 2) [30,36,44,48]. They are thought to be involved in several mechanisms of the immune system, such as regulation of B and $\mathrm{T}$ cell differentiation and development, and innate/adaptive immune responses [100,101]. In addition, microRNA can play key roles in autoimmune conditions, such as inflammatory bowel disease (IBD), and regulate the development or prevention of these diseases [102]. Therefore, they could potentially be used as milk biomarkers to diagnose immune disorders such as allergic conditions [103,104].

Kosaka et al. [48] reported high quantities of microRNAs in HM with functions associated with the immune system during the first 6 months of lactation, including, but not limited to miR-181a, miR-17, miR-155, miR-150, and miR-223. In particular, miR-181 and miR-155, which are known to regulate $B$ cell differentiation [48,105,106], are present in high concentrations in HM [44,48], suggesting a function in the development of the infant's immune system. 
Table 2. Immune-related microRNAs expressed in different fractions of milk from different mammalian species that have been highlighted in previous studies.

\begin{tabular}{|c|c|c|c|c|c|c|}
\hline MicroRNA & Regulatory Function(s) & References & Presence in HM & References & Presence in Animal Milk & References \\
\hline $\operatorname{miR}-181 \mathrm{a}$ & $\begin{array}{l}\text { Cell signaling. Development } \\
\text { of B cells. }\end{array}$ & {$[105,107]$} & Skim milk. Milk lipids. & {$[30,44,48]$} & $\begin{array}{l}\text { Bovine skim milk (colostrum and } \\
\text { mature milk). Rat milk whey. } \\
\text { Porcine milk exosomes. }\end{array}$ & {$[52,55,56]$} \\
\hline $\operatorname{miR}-181 b$ & $\begin{array}{l}\text { Switch recombination in } \\
\text { activated B cells. Increased } \\
\text { activity of NF- } \mathrm{kB} \text {. }\end{array}$ & {$[105,108,109]$} & $\begin{array}{l}\text { Skim milk (colostrum } \\
\text { and mature milk). } \\
\text { Milk lipids. }\end{array}$ & {$[30,44,48]$} & $\begin{array}{l}\text { Bovine skim milk (colostrum and } \\
\text { mature milk). Rat milk whey. } \\
\text { Porcine milk exosomes. }\end{array}$ & {$[52,55,56]$} \\
\hline miR-155 & $\begin{array}{l}\mathrm{B} \text { and } \mathrm{T} \text { cell differentiation. } \\
\text { Innate/adaptive } \\
\text { immune response. }\end{array}$ & {$[106,110,111]$} & $\begin{array}{l}\text { Skim milk (colostrum } \\
\text { and mature milk). Milk } \\
\text { lipids. Milk exosomes. }\end{array}$ & {$[30,36,44,48]$} & $\begin{array}{l}\text { Bovine skim milk } \\
\text { (colostrum and mature milk). }\end{array}$ & {$[52,54]$} \\
\hline $\operatorname{miR}-17$ & $\begin{array}{l}\mathrm{B} \text { and T cells. } \\
\text { Monocyte development. }\end{array}$ & {$[112,113]$} & $\begin{array}{l}\text { Skim milk. Milk lipids. } \\
\text { Milk exosomes. }\end{array}$ & {$[36,44,48]$} & $\begin{array}{l}\text { Bovine skim milk (colostrum and } \\
\text { mature milk). Rat milk whey. } \\
\text { Porcine milk exosomes. }\end{array}$ & {$[52,55,56]$} \\
\hline miR-92a & $\begin{array}{l}\text { B and T cells. Monocyte } \\
\text { development. Downregulated } \\
\text { in lymphoma. }\end{array}$ & {$[114,115]$} & $\begin{array}{l}\text { Skim milk (colostrum } \\
\text { and mature milk). } \\
\text { Milk lipids. }\end{array}$ & {$[30,44,48]$} & $\begin{array}{l}\text { Bovine skim milk (colostrum and } \\
\text { mature milk). Rat milk whey. } \\
\text { Porcine milk exosomes. }\end{array}$ & {$[52,54,55,56]$} \\
\hline $\operatorname{miR}-125 b$ & $\begin{array}{l}\text { Tumor necrosis factor- } \alpha \\
\text { production. Innate immune } \\
\text { response. TLR signaling. }\end{array}$ & [111] & $\begin{array}{l}\text { Skim milk (colostrum } \\
\text { and mature milk). } \\
\text { Milk lipids. }\end{array}$ & {$[30,44,48]$} & $\begin{array}{l}\text { Bovine skim milk (colostrum and } \\
\text { mature milk). Rat milk whey. } \\
\text { Porcine milk exosomes. }\end{array}$ & {$[52,54,55,56$} \\
\hline miR-146a & $\begin{array}{l}\text { Innate immune response. } \\
\text { TLR signaling. }\end{array}$ & {$[116,117]$} & $\begin{array}{l}\text { Skim milk (colostrum } \\
\text { and mature milk). Milk } \\
\text { lipids. Milk exosomes. }\end{array}$ & {$[30,36,44,48]$} & $\begin{array}{l}\text { Bovine skim milk } \\
\text { (colostrum and mature milk). }\end{array}$ & {$[52,55]$} \\
\hline miR-223 & $\begin{array}{l}\text { Neutrophil proliferation and } \\
\text { activation. Granulopoiesis. }\end{array}$ & {$[118,119,120]$} & $\begin{array}{l}\text { Skim milk. Milk lipids. } \\
\text { Milk exosomes. }\end{array}$ & {$[36,44,48]$} & $\begin{array}{l}\text { Bovine skim milk (colostrum and } \\
\text { mature milk). Rat milk whey. }\end{array}$ & {$[52,54,56]$} \\
\hline $\operatorname{miR}-150$ & $\begin{array}{l}\text { B and T cells. Suppresses B } \\
\text { cell differentiation. }\end{array}$ & {$[121,122]$} & $\begin{array}{l}\text { Skim milk. Milk lipids. } \\
\text { Milk exosomes. }\end{array}$ & {$[30,36,44,48]$} & $\begin{array}{l}\text { Bovine skim milk (colostrum and } \\
\text { mature milk). Rat milk whey. }\end{array}$ & {$[52,56]$} \\
\hline miR-30b & $\begin{array}{l}\text { Promotes induced cellular } \\
\text { invasion. Immune } \\
\text { suppression. }\end{array}$ & [123] & $\begin{array}{l}\text { Skim milk (colostrum } \\
\text { and mature milk). Milk } \\
\text { lipid. Milk exosomes. }\end{array}$ & {$[30,36,44]$} & $\begin{array}{l}\text { Bovine skim milk (colostrum and } \\
\text { mature milk). Rat milk whey. } \\
\text { Porcine milk exosomes. }\end{array}$ & {$[51,52,56]$} \\
\hline
\end{tabular}


Table 2. Cont.

\begin{tabular}{|c|c|c|c|c|c|c|}
\hline MicroRNA & Regulatory Function(s) & References & Presence in HM & References & Presence in Animal Milk & References \\
\hline $\operatorname{miR}-182$ & $\begin{array}{l}\text { Promotes IL-2 (interleukin- } \\
\text { 2). Induces T cell- } \\
\text { mediated immune } \\
\text { responses. }\end{array}$ & {$[124]$} & $\begin{array}{l}\text { Milk lipids. } \\
\text { Milk exosomes. }\end{array}$ & {$[36,44]$} & $\begin{array}{l}\text { Bovine skim milk (colostrum } \\
\text { and mature milk). Rat milk } \\
\text { whey. Porcine milk exosomes. }\end{array}$ & {$[51,52,56]$} \\
\hline $\operatorname{miR}-200 \mathrm{a}$ & $\begin{array}{l}\text { Associated with } \\
\text { Hodgkin lymphoma. }\end{array}$ & {$[125]$} & $\begin{array}{l}\text { Skim milk (colostrum } \\
\text { and mature milk). Milk } \\
\text { lipids. Milk exosomes. }\end{array}$ & {$[30,36,44]$} & $\begin{array}{l}\text { Bovine skim milk (colostrum } \\
\text { and mature milk). Rat milk } \\
\text { whey.Porcine milk exosomes. }\end{array}$ & {$[51,52,54,56]$} \\
\hline miR-29a & $\begin{array}{l}\text { Suppresses immune } \\
\text { responses to intracellular } \\
\text { pathogens. Downregulated } \\
\text { in B cell chronic } \\
\text { lymphocytic leukemia. }\end{array}$ & {$[126,127]$} & $\begin{array}{l}\text { Skim milk (colostrum } \\
\text { and mature milk). Milk } \\
\text { lipids. Milk exosomes. }\end{array}$ & {$[30,36,44]$} & $\begin{array}{l}\text { Bovine skim milk (colostrum } \\
\text { and mature milk). Rat milk } \\
\text { whey. Porcine milk exosomes. }\end{array}$ & {$[52,54,55,56]$} \\
\hline $\operatorname{miR}-15 a$ & $\begin{array}{l}\text { Downregulated in chronic } \\
\text { lymphocytic leukemia. }\end{array}$ & {$[128,129]$} & $\begin{array}{l}\text { Skim milk (colostrum } \\
\text { and mature milk). Milk } \\
\text { lipid. Milk exosomes. }\end{array}$ & {$[30,36,44]$} & $\begin{array}{l}\text { Bovine skim milk (colostrum } \\
\text { and mature milk). } \\
\text { Porcine milk exosomes. }\end{array}$ & {$[52,54,55]$} \\
\hline miR-16 & $\begin{array}{l}\text { Induces TNF mRNA } \\
\text { degradation. Upregulated } \\
\text { in rheumatoid arthritis. } \\
\end{array}$ & {$[20,130]$} & Skim milk. Milk lipids. & {$[30,44]$} & $\begin{array}{l}\text { Bovine skim milk (colostrum } \\
\text { and mature milk). Rat milk } \\
\text { whey. Porcine milk exosomes. }\end{array}$ & {$[52,55,56]$} \\
\hline $\operatorname{miR}-21$ & $\begin{array}{l}\text { Up-regulated in B-cell } \\
\text { lymphoma and chronic } \\
\text { lymphocytic leukemia. }\end{array}$ & {$[131]$} & $\begin{array}{l}\text { Skim milk (colostrum } \\
\text { and mature milk). Milk } \\
\text { lipids. Milk exosomes. }\end{array}$ & {$[30,36,44]$} & $\begin{array}{l}\text { Bovine skim milk (colostrum } \\
\text { and mature milk). Rat milk } \\
\text { whey. Porcine milk exosomes. }\end{array}$ & {$[51,52,55,56]$} \\
\hline miR-20a & $\begin{array}{l}\text { Inhibits monocyte } \\
\text { proliferation, } \\
\text { differentiation and } \\
\text { maturation. }\end{array}$ & {$[112]$} & $\begin{array}{l}\text { Skim milk (colostrum } \\
\text { and mature milk). Milk } \\
\text { lipids. Milk exosomes. }\end{array}$ & {$[30,36,44]$} & $\begin{array}{l}\text { Bovine skim milk (colostrum } \\
\text { and mature milk). Rat milk } \\
\text { whey. }\end{array}$ & {$[52,54,56]$} \\
\hline miR-106a & $\begin{array}{l}\text { Inhibits monocyte } \\
\text { proliferation, } \\
\text { differentiation and } \\
\text { maturation. }\end{array}$ & {$[112]$} & $\begin{array}{l}\text { Milk lipids. } \\
\text { Milk exosomes. }\end{array}$ & {$[36,44]$} & $\begin{array}{l}\text { Bovine skim milk (colostrum } \\
\text { and mature milk). Porcine milk } \\
\text { exosomes. }\end{array}$ & {$[52,54,55]$} \\
\hline
\end{tabular}


In addition, microRNA clusters miR-17 and miR-92 have been detected at high levels in HM, and given their function in regulating monocyte development as well as $\mathrm{B}$ and $\mathrm{T}$ cell differentiation and maturation $[18,132]$, they are also thought to contribute to the maturation of the infant's immune system early in life. miR-223, which is predicted to activate proliferation of granulocytes [119], is also found at high levels in HM [48]. HM is rich in B cell-related microRNAs, such as miR-181 and miR-155, which potentially induce B cell differentiation $[108,110]$. On the other hand, miR-150, which is present in lower concentrations in HM, is known to act as a B cell suppressor [121,122]. Interestingly, Zhou and colleagues identified a large number of microRNAs in HM exosomes [36]. Of the 10 most abundant, 4 microRNAs were associated with immune functions, including miR-148a-3p, miR-30b-5p, miR- 182-5p, and miR-200a-3p [36]. Specifically, miR-30b-5p is known to induce immunosuppression and reduce immune cell activation [123]. In contrast, miR-182-5p induces $\mathrm{T}$ cell-mediated immune responses [124]. In the same study, 59 pre-microRNAs out of 87 (67.8\%) that were detected in HM exosomes are considered to have immunological functions [36], which is consistent with a previous study in human skim milk microRNA [48]. The miR-17-92 cluster was also highly expressed in HM exosomes, with a speculated function as a developmental regulator of the immune system [19].

Some microRNAs present in milk may have more than one function. Interestingly, miR-17-92, which is known to have immunological functions, has also been implicated in oncogenesis by promoting cell proliferation and inhibiting apoptosis [133], although its role in the breastfed infant is poorly understood. Given that genes known to act as oncogenes have recently also been implicated in normal lactation $[58,134,135]$, it can be hypothesised that miRN-17-92, as well as other microRNAs with similar functions may participate in the milk-secretory function of the lactating breast rather than act as oncogenes in the context of lactation and breastfeeding. Some of these microRNAs therefore may be indicators of lactation performance.

In addition to HM, microRNAs with immunological functions have been identified in the milk of other mammalian species [51-54]. Profiling of bovine milk showed a high similarity of microRNA content to HM in respect to immune-related microRNAs [48,52,53], although this does not directly translate to the human infant. miR-181a and miR-155, which play important roles in immune system regulation and inflammation [44,136], were profiled in both bovine colostrum and mature milk, and were detected in high quantities, more so in colostrum [52,53]. More specifically, bovine immune-related microRNAs are present at higher concentrations in colostrum compared to mature milk [52], although this is yet to be investigated in HM. This appears to be one of the factors involved in providing greater immunological support required early in life, and is consistent with the higher numbers of immune cells and concentrations of various humoral immunological factors such as lactoferrin and secretory IgA in colostrum compared to mature HM [58,62,137-139]. Bovine milk miR-15b, miR-27b, miR-34a, miR-106b, miR-130a, miR-155, and miR-223, which are all considered as immune- and development-related microRNAs, have been found in higher levels in colostrum than in mature milk [54]. Additionally, the expression levels of a selected bovine microRNA group, including miR-223, miR-106b, miR-15b, miR-155, and miR-34a, have been analyzed using qPCR and compared between colostrum and mature milk, where they were found to be present at significantly different levels [54]. In contrast to bovine milk [52-54], rat skim milk [56] and porcine milk exosomes [51], a study showed that the levels of microRNA concentration and expression in HM 
are lower in colostrum compared to mature milk, where 429 different microRNAs were identified in human mature milk vs. 386 different microRNAs in human colostrum [30]. This warrants validation, together with investigation of differences in immune-related microRNAs between human colostrum and mature HM, since these molecules are likely to contribute in the immunoprotection of the neonate in the first days postpartum when it is most susceptible, as well as in the development of infant's immune system and long-term protection against infections.

Kosaka et al. [48] and Gu et al. [51] first showed that human skim milk and porcine milk exosomes, respectively, contain microRNAs related to immune responses (Table 2). Gu et al. found that 58 out of 84 immune-related microRNAs listed in the Pathway Central Database (Qiagen, Valencia, CA, USA) were enriched in porcine milk exosomes [51], consistent with another recent study showing that HM exosomes were enriched with immune-related microRNA [36]. This study identified 12 out of 13 high abundance microRNAs in porcine milk exosomes to be expressed at higher levels in the first 3 days postpartum compared to later in month 1 postpartum (days 7, 14, 21 and 28) [51]. These 12 microRNAs (let-7a-5p, miR-182-5p, miR-191-5p, miR-200c-3p, miR-21-5p, miR-25-3p, miR27b-3p, miR-30a-5p, miR-30c-2-5p \& -1-5p, miR-30d-5p, miR-375-3p, and miR-574-3p) [51] are all immune-related and they regulate immune response genes and proteins [140]. More specifically, miR-30c-2-5p and miR-1$5 \mathrm{p}$ are immunosuppression regulators [123], whereas let-7a-1-5p regulates inflammation-associated cytokine IL-6 (interleukin-6) that induces STAT3 (signal transducers and activators of transcription 3) signaling [141]. The innate immune receptors can be activated and regulated by porcine milk miR-21$5 \mathrm{p}$, toll-like receptor 4 (TLR4), and a key cytokine receptor via targeting programmed cell death protein 4 (PDCD4) and interleukin 12 (IL-12), respectively [142]. Also, IL-12 that is negatively controlled by miR-21-5p, is also responsible for regulating T cells and natural killer cells [143]. Further, the abundant porcine milk miR-27b was found to induce lipopolysaccharide (LPS), which inhibits and de-stabilizes the peroxisome proliferator-activated receptor $\mathrm{c}$ (PPARc), which is important in dampening inflammation via macrophage immune response [144].

Several bovine immune-related microRNAs [100,101] have been isolated from milk-derived microvesicles [53], and were also found to be expressed in the mammary gland using small RNA sequencing (Table 2) [145]. These microRNAs include miR101 and miR150, which are known regulators of T cells [146,147], and also miR-223 that has been reported to modulate innate immune cell (granulocytes and neutrophils) differentiation and activation [100,119,120]. miR-155 and miR-223 have been detected in bovine milk and are both involved in many immune functions [100], and potentially have anti-inflammatory effects especially in bovine colostrum. In addition to this function, miR-155 regulates $\mathrm{T}$ and $\mathrm{B}$ cell differentiation, and is a known modulator of $\mathrm{T}$ helper cells (Th1/Th2 balance) [148]. In contrast, miR-223 negatively regulates neutrophil proliferation and activation [100]. miR-25-3p targets KLF4, which is a potent mediator of inflammation [149], and has a crucial role in the development of the immune system [51]. miR-30a-5p targets GalNActransferase 7 (GALNT7) to promote cellular invasion and immunosuppression [123]. miR-182-5p promotes $\mathrm{T}$ cell-mediated immune responses by inhibiting forkhead box protein O1 (FOXO1) [124], a gene that is also targeted by miR-21 in cancer $[150,151]$. miR-200c-3p has been identified to regulate $\mathrm{T}$ cell differentiation by targeting zinc finger E-box-binding homeobox 1 (ZEB1) [152], and also to regulate CD4 differentiation [153]. Moreover, as mentioned earlier, bovine milk microRNA expression patterns have been recently found to be altered during severe inflammation of mammary gland such as mastitis [71]. Gene target 
analysis of the up- and down-regulated milk microRNAs such as miR-223 and miR-15b, respectively, revealed several roles of these microRNAs in response to mastitis [154]. Also, most milk microRNAs were downregulated during mastitis, suggesting that they actively control the mammary immune response to $S$. uberis, which causes mastitis in the dairy cow [154].

Collectively, the current data highlight that breastmilk is a complex system of different microRNA molecules with synergistic and antagonistic relationships, controlling specific immune responses in the infant and the lactating breast $[36,42,44,48]$. Factors such as the stage of lactation (colostrum vs. mature milk) and infection/inflammation have been shown to influence the microRNA-mediated epigenetic regulation of immune responses and development in both the infant and the lactating breast, further supporting the potential use of these molecules diagnostically.

\section{3. microRNAs Are Key Regulators of Milk Lipid Metabolism}

MicroRNAs have been isolated from HM lipid vesicles including fat globules in large numbers [44], as well as from milk cells and skim milk [44,46,155]. This has formed the basis for the potential use of both extracellular and intra-vesicle milk microRNAs as biomarkers in molecular diagnostics for a range of diseases [156]. Although lipid metabolism is usually regulated extracellularly, microRNAs have recently been identified to regulate genes associated with lipid metabolism at the post-transcriptional level [155]. These genes control functions related to cholesterol homeostasis, fatty acid oxidation, and lipogenesis, offering new opportunities for the treatment of various diseases such as dyslipidemias [157].

The known lipid regulatory microRNAs are few and include amongst others miR-335, miR-33, miR-122, miR-370, miR-378-3p, and miR-125a-5p [157]. Interestingly, these microRNAs have been identified in abundance in the HM lipid fraction [44], human skim milk [30], HM cells [35], human colostrum [30], HM exosomes [36], as well as in bovine skim milk and colostrum [52], suggesting that they play critical roles in the lipid metabolism and/or synthesis in the lactating breast. For example, miR-33 has been shown to regulate cholesterol homeostasis at the cellular level $[158,159]$. One of the most significant predicted gene targets of miR-33 is ABCA1, which produces cholesterol efflux regulatory protein (CERP). CERP is responsible for regulating cellular cholesterol and phosphate homeostasis, and also transporting cholesterol outside of the cell [160]. miR-33 also targets ABCG1, which reduces the efflux of cholesterol to high-density lipoprotein (HDL) and serum in macrophages [156,161].

miR-125a-5p is another microRNA found abundantly in human and other species milk, regulating oxysterol binding protein-related Protein 9 (ORP9) [162], which is involved in various processes of lipid metabolism [163,164] including induction of lipid uptake by macrophages [162]. Furthermore, HM miR-103 [30,44] is known to regulate milk fat synthesis, promoting fat globule synthesis and accumulation of triglyceride and unsaturated fatty acids [165]. Overexpression of miR-103 has been identified as a crucial regulator of milk fat synthesis and composition as well as milk nutrient levels [165]. Interestingly, downregulation of miR-103 was not shown to affect fat accumulation in caprine milk lactocytes, suggesting that there may be alternative and/or compensatory mechanisms controlling mammary fat metabolism [165]. Further, miR-193b and miR-365, also present in milk, were shown to control lipid synthesis, upregulating brown fat differentiation via enhancing expression of Runt-related transcription factor 1 translocated to 1 (Runx1t1) [166]. 
Interestingly, in addition to fat globule-related microRNA, many microRNA have been found to be packaged into other lipid-based carriers, such as exosomes, microvesicles and apoptotic bodies, which are secreted by various cell types, such as immune cells [167], and many of which are found in HM [36]. These are known as lipid particle carriers [168,169], packaging not only microRNA, but also lipoproteins [155], and have the important function of delivering extracellular microRNA to recipient cells. For example, miR-150 is transported via microvesicles from macrophage-like cells to human microvascular endothelial cells, where it is thought to target c-Myb and regulate cell migration [122,170,171]. Moreover, adipocyte-derived microRNA such as miR-27a, miR-146b and miR-16, are transported to other cell recipients via microvesicles [171]. Therefore, it can be postulated that microRNAs contained in milk microvesicles/exosomes as well as fat globules are transferred to recipient cells in the GI tract of infants, and a proportion may transfer to the blood circulation from where they are transported to the infant's tissues, playing regulatory functions.

\subsection{Various Potential Benefits of Human Milk microRNAs}

The function of extracellular microRNA is still poorly understood [48]. Current evidence supports the notion that extracellular microRNAs play crucial roles in cell-cell communication $[42,172,173]$. microRNAs have been shown to be exported by cells in culture [42]. Moreover, proteins and mRNA can be taken up by neurons through exosomes from adjacent cells, suggesting that the same is possible for microRNA [42]. The existence of microRNA in exosomes and their potential function as extracellular regulators have opened up a new field of possibilities for use of microRNAs as biomarkers in health and disease [86,88] as well as in therapeutic modeling [174,175].

HM microRNA are potentially involved in many physiopathological functions, including regulating cell growth and differentiation [48] as well as influencing development in the infant [52]. For example, one of the most highly expressed microRNA in HM, miR-148a-3p [35,44], which is also found in other species' milk [51,52], targets DNA methyltransferase 3b (DNMT3B) and suppresses its expression, potentially to facilitate DNA methylation during development [176]. At the same time, given that the majority of cells in mature HM under healthy conditions are lactocytes [58], HM microRNA are reflective of the microRNA composition and function of the lactating mammary epithelium, and this can form the basis for further explorations of their use as non-invasive, easily accessible biomarker of the functionality of the lactating breast.

Moreover, some tissue-related microRNAs have been found in HM [48], but less abundantly than in tissue and organs [36]. For example, miR-142-5p and miR-142-3p (hematopoietic system), miR-122 (liver), and miR-216 and miR-217 (pancreas) were highly expressed in these organs and less abundantly in HM $[48,177]$, suggesting that these HM microRNAs may originate from the maternal bloodstream to specifically target the development, growth and function of the corresponding organs in the HM fed infant. At the same time, they may have specialized functions in the breast during lactation. Similarly in bovine milk, microRNA have been identified as tissue-specific microRNA present in low quantities in milk and with lower expression in both bovine colostrum and mature milk [52]. These include for example muscle miR-1 and miR-133 [173], brain miR-9 and miR-124a [178], pancreatic miR-216 and miR-217 [179], liver miR-122 [21,173], blood cell miR-451 [180], and endothelial cell miR-126 [181]. 
microRNAs isolated from HM fat globules have been shown to be regulated by a maternal high-fat diet, and this may modify metabolic pathways in HM fed infants [44]. This is in agreement with the putative roles of circulating microRNAs, which when altered in either composition or concentration can be associated with cardiovascular morbidity and mortality [182,183]. Munch et al. found that gene targets of 308 microRNAs in HM lipids have a wide range of functions, particularly in the regulation of gene expression and metabolism, and immune responses [44], suggesting the potential importance of these microRNAs for HM fed infants [44,184]. Further to these functions, some HM microRNA are thought to participate in the regulation of the central nervous system (CNS). For example, Munch et al. [44] showed that HM miR-118.2 targets Teneurin Transmembrane Protein 2 (TENM2), the encoding protein of which is found at high levels in the CNS [185], suggesting a regulatory function in the infant's neural development and promotion of connection formation within the nervous system [186,187]. Adipogenesis may also be targeted in the infant via milk-derived microRNAs. Overexpression of miR-155 [54] has been speculated to decrease brown adipose tissue mass by targeting the adipogenic transcription factor CCAAT/enhancer-binding protein $\beta$ (C/EBP $\beta)$ [188]. Milk-derived miR-29a inactivates the INSIG-1 gene [30,44,52], which is likely to regulate adipogenesis [189], and this was positively associated with body max index (BMI) [190]. In addition to direct effects on fat deposition, milk microRNA may be involved in the short- and/or long-term appetite control conferred to the infant via breastfeeding, together with the numerous appetite regulatory hormones of breastmilk, such as leptin, adiponectin, ghrelin, insulin and others [191].

In addition to their involvement in normal metabolism and tissue function, many microRNAs have been shown to target genes related to cancer [192,193], with some of these gene targets known to increase or decrease cancer risk. These microRNAs could be used as cancer biomarkers for both prognosis and diagnosis [43] and some of them are present in milk, and more specifically in HM. Although epidemiological evidence has previously associated bovine milk consumption with increased risk of certain cancers in adults [194-199], and this could be related to the content of bovine milk in oncogenic microRNA [200], the microRNAs in HM appear to have normal lactation-specific functions for the lactating mammary gland and the infant [45]. Interestingly, HM microRNA have been proposed to protect the infant against cancer through to adulthood [44]. For example, miR-21, which is present in both HM and bovine milk [36,52], is also known to be overexpressed in human hepatocellular cancer (HCC). Therefore, any deregulation of miR-21 can be associated with HCC growth by modulating mTORC1 signaling, i.e., PTEN expression [201]. miR-21 is an abundant microRNA in bovine milk [52] and has been isolated from both colostrum and mature HM [30]. It is also abundant in human plasma [202], and in infants it is thought to be involved in promoting postnatal growth [203]. In addition, miR-21 has other normal tissue functions, including regulation of adipogenic differentiation in mesenchymal stem cells (MSCs) of human adipose tissue [204]. Further, HM microRNAs may directly regulate tumor suppressor genes [205], such as the let-7 family, which is involved in decreasing lung tumor growth by directly targeting the RAS oncogene [206]. The specific normal functions of HM microRNA for the infant and in the lactating breast warrant further investigation. 


\section{Infant Formula is Poor in microRNAs Compared to Human Milk}

HM is much more than nutrition for the infant, containing fat, carbohydrates, proteins, vitamins and minerals, but also immunoprotetive and regulatory biomolecules as well as viable cells that provide essential signals for the infant's optimal growth, development and protection [70,191,207-209]. However, a rapid worldwide population growth over the last 100 years, and the high demand to provide artificial milk for infants has led scientists and industrial companies to successfully produce infant formula from bovine milk as an alternative or complementary food for infants initially without access to HM [210]. And although many have expressed the view that infant formula should only be made available to the infant if mother's own milk is not sufficient, infant formula has recently become controversially more popular within some communities for non-medical reasons [211].

HM is a complex biofluid containing maternal somatic cells, beneficial microbiota, and molecules including microRNAs with functional roles [30,134,212-214]. Most infant formulae are bovine milk-based [44], and similar to HM, bovine milk microRNAs are most likely to be highly conserved in both fat globules (lipid fraction) and cells. Due to their stability, microRNAs may largely survive the industrial milk preparation procedures, however the milk cell and lipid fractions are usually discarded from formula [215,216], so the microRNA presence in formulae is significantly reduced. This has been confirmed by studies showing that the expression level of microRNAs in formulae is much lower than that of raw bovine milk (Table 3) [52,54,217]. Chen et al. selected and surveyed seven microRNAs as quality control markers for raw milk and different brands of infant formula [52]. The expression level of these seven microRNAs was significantly lower in formulae compared to raw milk [52]. Izumi et al. found that the total RNA concentration of three types of infant formulae (standard formula, follow-on formula, and extensively hydrolyzed formula) was significantly lower than in raw bovine milk [54]. Also, two highly expressed microRNAs (miR-148a and miR-200c) in bovine milk were differentially expressed among the three different types of infant formula [54]. In a recent study, we have compared the human microRNA content and expression levels of two infant formulae from the Australian market, a bovine-milk based and a soy-based formula [46]. Out of 754 human mature microRNAs tested using Taqman Openarray (Applied Biosystems), only 45 microRNAs were identified in the bovine milk formula, and only 22 microRNAs in the soy formula [46], (Table 3). Moreover, the biological activity of the remaining few formula microRNAs may be altered by the formula processing procedures, something that requires further investigation. Although the functional effects of non-human milk microRNAs on infants have not been investigated, it is possible that some microRNAs that are shared between bovine and human milk may play similar beneficial functions for the offspring across mammals, emphasizing the potential detrimental effects for infants of the low microRNA content of artificial formulae. This, together with the near absence in formulae of other immunoprotective factors of HM are likely to at least partially explain the reduction in protection from disease in infants fed artificial formulae [217]. Donor milk is the preferred alternative to formula, and even if pasteurized, donor milk is likely to retain many HM microRNA, potentially conferring more benefits to the infant than formula. 
Table 3. Comparison of selected microRNAs and their abundance in infant formulae, bovine milk, and human milk (HM).

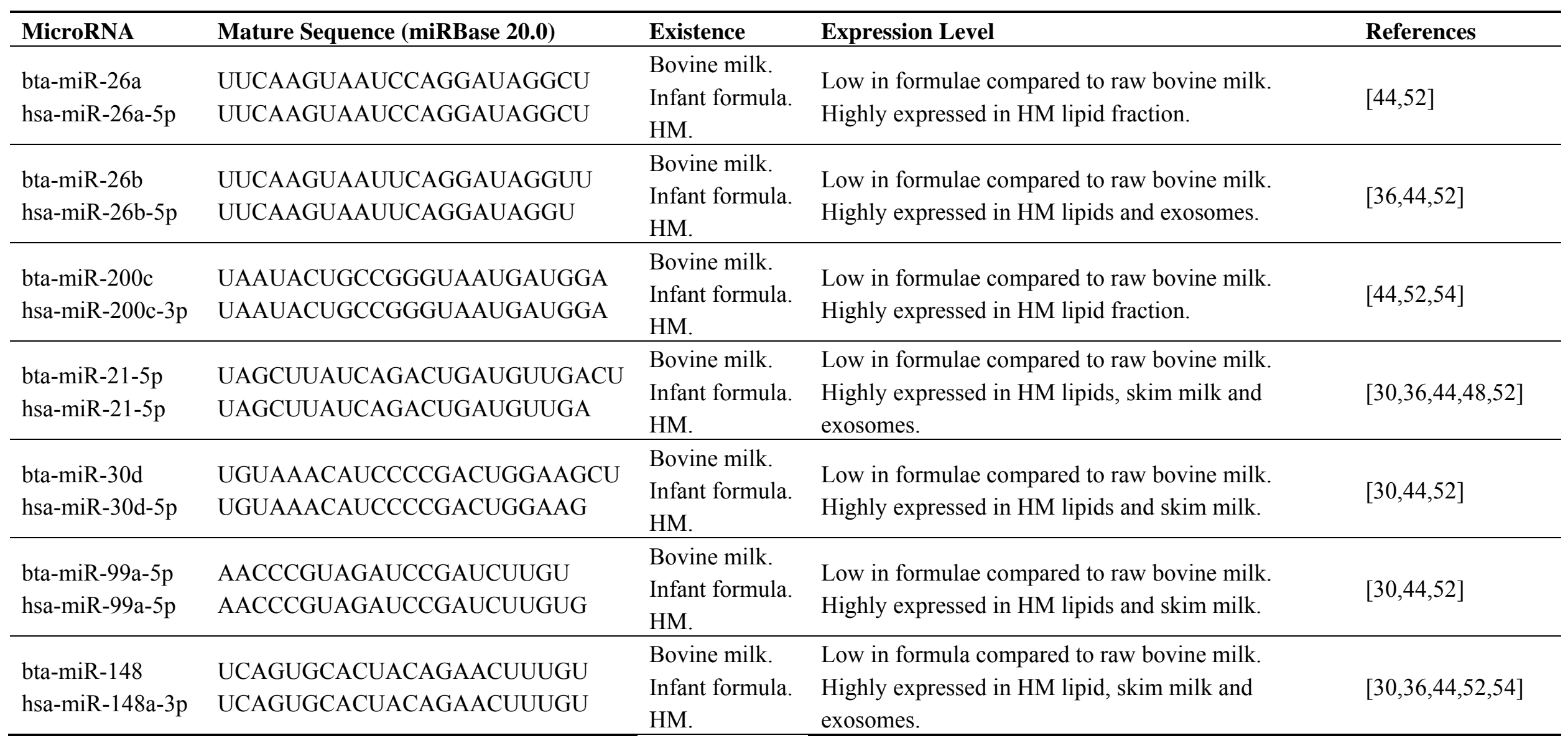




\section{Conclusions and Outlook}

microRNAs play beneficial functions in humans and are actively involved in many normal developmental and physiological processes. They are crucial modulators of many normal functions, such as cardiac function and other cardiovascular processes, immune protection, and tissue function [218]. Deregulation of microRNAs has also been shown to be associated with disease, for which they are useful diagnostic biomarkers [192,219]. The recent discovery and identification of microRNA in HM requires further study to elucidate the biology of microRNA and their normal functions in the development and protection of the human breast and the infant. Although the use of circulating microRNA as biomarkers is still in its infancy [156], microRNA have been proposed as biomarkers for various abnormalities [86], including breast cancer [220,221] and more recently, milk microRNA as biomarkers for lactation performance [52] and mastitis [71]. This is of particular interest since milk can be accessed easily and non-invasively and is plentiful. Importantly, microRNAs are extremely stable, and are transferred to humans via food, and also to infants via HM. Infant formula not only contains insufficient amounts of biologically active microRNAs, but it also has a completely different microRNA profile to human milk, with potential detrimental effects on the growth, development and protection of the infant. The investigation of the roles of HM microRNA for the infant and the mother will not only reveal novel attributes of breastfeeding, but it may also open new diagnostic and therapeutic avenues.

\section{Acknowledgements}

Foteini Kakulas, Donna T. Geddes and Peter E. Hartmann received an unrestricted research grant from Medela AG (Switzerland). The company had no input in writing or the decision to publish the manuscript. Mohammed Alsaweed received a PhD scholarship from Majmaah University, Riyadh, Saudi Arabia. The authors would like to acknowledge Donna Savigni for her editorial input.

\section{Author Contributions}

Mohammed Alsaweed and Foteini Kakulas wrote the manuscript. Peter E. Hartmann and Donna T. Geddes critically reviewed the manuscript.

\section{Conflicts of Interest}

The authors declare no conflict of interest.

\section{References}

1. Lee, R.C.; Feinbaum, R.L.; Ambros, V. The C. elegans heterochronic gene lin-4 encodes small RNAs with antisense complementarity to lin-14. Cell 1993, 75, 843-854.

2. Bartel, D.P. MicroRNAs: Genomics, biogenesis, mechanism, and function. Cell 2004, 116, 281-297.

3. He, L.; Hannon, G.J. MicroRNAs: Small RNAs with a big role in gene regulation. Nat. Rev. Genet. 2004, 5, 522-531. 
4. Pritchard, C.C.; Cheng, H.H.; Tewari, M. MicroRNA profiling: Approaches and considerations. Nat. Rev. Genet. 2012, 13, 358-369.

5. Fabian, M.R.; Sonenberg, N.; Filipowicz, W. Regulation of mRNA translation and stability by microRNAs. Annu. Rev. Biochem. 2010, 79, 351-379.

6. Krol, J.; Loedige, I.; Filipowicz, W. The widespread regulation of microRNA biogenesis, function and decay. Nat. Rev. Genet. 2010, 11, 597-610.

7. Winter, J.; Jung, S.; Keller, S.; Gregory, R.I.; Diederichs, S. Many roads to maturity: microRNA biogenesis pathways and their regulation. Nat. Cell Biol. 2009, 11, 228-234.

8. Kim, V.N.; Han, J.; Siomi, M.C. Biogenesis of small RNAs in animals. Nat. Rev. Mol. Cell Biol. 2009, 10, 126-139.

9. Du, T.; Zamore, P.D. microPrimer: The biogenesis and function of microRNA. Development 2005, 132, 4645-4652.

10. International Human Genome Sequencing, C. Finishing the euchromatic sequence of the human genome. Nature 2004, 431, 931-945.

11. Williams, A.E. Functional aspects of animal microRNAs. Cell. Mol. Life Sci. 2008, 65, 545-562.

12. O'Driscoll, L. The emerging world of microRNAs. Anticancer Res. 2006, 26, 4271-4278.

13. Houbaviy, H.B.; Murray, M.F.; Sharp, P.A. Embryonic stem cell-specific MicroRNAs. Dev. Cell 2003, 5, 351-358.

14. Judson, R.L.; Babiarz, J.E.; Venere, M.; Blelloch, R. Embryonic stem cell-specific microRNAs promote induced pluripotency. Nat. Biotechnol. 2009, 27, 459-461.

15. $\mathrm{Xu}, \mathrm{N}$.; Papagiannakopoulos, T.; Pan, G.; Thomson, J.A.; Kosik, K.S. MicroRNA-145 regulates OCT4, SOX2, and KLF4 and represses pluripotency in human embryonic stem cells. Cell 2009, 137, 647-658.

16. Huangfu, D.; Maehr, R.; Guo, W.; Eijkelenboom, A.; Snitow, M.; Chen, A.E.; Melton, D.A. Induction of pluripotent stem cells by defined factors is greatly improved by small-molecule compounds. Nat. Biotechnol. 2008, 26, 795-797.

17. Yoshida, Y.; Takahashi, K.; Okita, K.; Ichisaka, T.; Yamanaka, S. Hypoxia enhances the generation of induced pluripotent stem cells. Cell Stem Cell 2009, 5, 237-241.

18. Ventura, A.; Young, A.G.; Winslow, M.M.; Lintault, L.; Meissner, A.; Erkeland, S.J.; Newman, J.; Bronson, R.T.; Crowley, D.; Stone, J.R.; et al. Targeted deletion reveals essential and overlapping functions of the miR-17 through 92 family of miRNA clusters. Cell 2008, 132, 875-886.

19. Xiao, C.; Srinivasan, L.; Calado, D.P.; Patterson, H.C.; Zhang, B.; Wang, J.; Henderson, J.M.; Kutok, J.L.; Rajewsky, K. Lymphoproliferative disease and autoimmunity in mice with increased miR-17-92 expression in lymphocytes. Nat. Immunol. 2008, 9, 405-414.

20. Jing, Q.; Huang, S.; Guth, S.; Zarubin, T.; Motoyama, A.; Chen, J.; Di Padova, F.; Lin, S.C.; Gram, H.; Han, J. Involvement of microRNA in AU-rich element-mediated mRNA instability. Cell 2005, 120, 623-634.

21. Landgraf, P.; Rusu, M.; Sheridan, R.; Sewer, A.; Iovino, N.; Aravin, A.; Pfeffer, S.; Rice, A.; Kamphorst, A.O.; Landthaler, M.; et al. A mammalian microRNA expression atlas based on small RNA library sequencing. Cell 2007, 129, 1401-1414. 
22. O’Connell, R.M.; Taganov, K.D.; Boldin, M.P.; Cheng, G.; Baltimore, D. MicroRNA-155 is induced during the macrophage inflammatory response. Proc. Natl. Acad. Sci. USA 2007, 104, 1604-1609.

23. Monticelli, S.; Ansel, K.M.; Xiao, C.; Socci, N.D.; Krichevsky, A.M.; Thai, T.H.; Rajewsky, N.; Marks, D.S.; Sander, C.; Rajewsky, K.; et al. MicroRNA profiling of the murine hematopoietic system. Genome Biol. 2005, doi:10.1186/gb-2005-6-8-r71.

24. Yang, B.; Lin, H.; Xiao, J.; Lu, Y.; Luo, X.; Li, B.; Zhang, Y.; Xu, C.; Bai, Y.; Wang, H.; et al. The muscle-specific microRNA miR-1 regulates cardiac arrhythmogenic potential by targeting GJA1 and KCNJ2. Nat. Med. 2007, 13, 486-491.

25. Poy, M.N.; Eliasson, L.; Krutzfeldt, J.; Kuwajima, S.; Ma, X.; Macdonald, P.E.; Pfeffer, S.; Tuschl, T.; Rajewsky, N.; Rorsman, P.; et al. A pancreatic islet-specific microRNA regulates insulin secretion. Nature 2004, 432, 226-230.

26. Giraldez, A.J.; Cinalli, R.M.; Glasner, M.E.; Enright, A.J.; Thomson, J.M.; Baskerville, S.; Hammond, S.M.; Bartel, D.P.; Schier, A.F. MicroRNAs regulate brain morphogenesis in zebrafish. Science 2005, 308, 833-838.

27. Mahn, R.; Heukamp, L.C.; Rogenhofer, S.; von Ruecker, A.; Muller, S.C.; Ellinger, J. Circulating microRNAs (miRNA) in serum of patients with prostate cancer. Urology 2011, doi:10.1016/j.urology.2011.01.020.

28. Gotte, M. MicroRNAs in breast cancer pathogenesis. Minerva Ginecol. 2010, 62, 559-571.

29. Si, M.L.; Zhu, S.; Wu, H.; Lu, Z.; Wu, F.; Mo, Y.Y. miR-21-mediated tumor growth. Oncogene 2007, 26, 2799-2803.

30. Weber, J.A.; Baxter, D.H.; Zhang, S.; Huang, D.Y.; Huang, K.H.; Lee, M.J.; Galas, D.J.; Wang, K. The microRNA spectrum in 12 body fluids. Clin. Chem. 2010, 56, 1733-1741.

31. Silveri, L.; Tilly, G.; Vilotte, J.L.; Le Provost, F. MicroRNA involvement in mammary gland development and breast cancer. Reprod. Nutr. Dev. 2006, 46, 549-556.

32. Zhang, L.; Hou, D.; Chen, X.; Li, D.; Zhu, L.; Zhang, Y.; Li, J.; Bian, Z.; Liang, X.; Cai, X.; et al. Exogenous plant MIR168a specifically targets mammalian LDLRAP1: Evidence of cross-kingdom regulation by microRNA. Cell Res. 2012, 22, 107-126.

33. Palmer, J.D.; Soule, B.P.; Simone, B.A.; Zaorsky, N.G.; Jin, L.; Simone, N.L. Dietary alterations caused by microRNA: Can food be medicinal? Ageing Res. Rev. 2014, doi:10.1016/j.arr.2014.04.005.

34. Jiang, M.; Sang, X.; Hong, Z. Beyond nutrients: Food-derived microRNAs provide cross-kingdom regulation. Bioessays 2012, 34, 280-284.

35. Alsaweed, M.; Tat-Lai, C.; Newnham, J.; Hartmann, P.E.; Geddes, D.T.; Kakulas, F. Small RNA Sequencing of Human Milk Cells reveals Numerous Known and Novel miRNAs that may be affected by Milk Removal. In Proceedings of the Combined Biological Sciences Meeting, Perth, Australia, 28 August 2015.

36. Zhou, Q.; Li, M.; Wang, X.; Li, Q.; Wang, T.; Zhu, Q.; Zhou, X.; Wang, X.; Gao, X.; Li, X. Immune-related microRNAs are abundant in breast milk exosomes. Int. J. Biol. Sci. 2012, 8, 118-123. 
37. Baier, S.R.; Nguyen, C.; Xie, F.; Wood, J.R.; Zempleni, J. MicroRNAs are absorbed in biologically meaningful amounts from nutritionally relevant doses of cow milk and affect gene expression in peripheral blood mononuclear cells, HEK-293 kidney cell cultures, and mouse livers. J. Nutr. 2014, 144, 1495-1500.

38. Wolf, T.; Baier, S.R.; Zempleni, J. The intestinal transport of bovine milk exosomes is mediated by endocytosis in human colon carcinoma Caco-2 cells and rat small intestinal IEC-6 cells. J. Nutr. 2015, doi:10.3945/jn.115.218586.

39. Pieters, B.C.; Arntz, O.J.; Bennink, M.B.; Broeren, M.G.; van Caam, A.P.; Koenders, M.I.; van Lent, P.L.; van den Berg, W.B.; de Vries, M.; van der Kraan, P.M.; et al. Commercial cow milk contains physically stable extracellular vesicles expressing immunoregulatory TGF-beta. PLOS ONE 2015, doi:10.1371/journal.pone.0121123.

40. Kramer, M.S. "Breast is best": The evidence. Early Hum. Dev. 2010, 86, 729-732.

41. Kramer, M.S.; Kakuma, R. The optimal duration of exclusive breastfeeding. J. Adv. Nurs. 2001, 35, 313-315.

42. Wang, K.; Zhang, S.; Weber, J.; Baxter, D.; Galas, D.J. Export of microRNAs and microRNA-protective protein by mammalian cells. Nucleic Acids Res. 2010, 38, 7248-7259.

43. Kosaka, N.; Iguchi, H.; Ochiya, T. Circulating microRNA in body fluid: A new potential biomarker for cancer diagnosis and prognosis. Cancer Sci. 2010, 101, 2087-2092.

44. Munch, E.M.; Harris, R.A.; Mohammad, M.; Benham, A.L.; Pejerrey, S.M.; Showalter, L.; $\mathrm{Hu}$, M.; Shope, C.D.; Maningat, P.D.; Gunaratne, P.H.; et al. Transcriptome profiling of microRNA by Next-Gen deep sequencing reveals known and novel miRNA species in the lipid fraction of human breast milk. PLOS ONE 2013, doi:10.1371/journal.pone.0050564.

45. Alsaweed, M.; Tat-Lai, C.; Newnham, J.; Hartmann, P.E.; Geddes, D.T.; Kakulas, F. Breastmilk miRNA Primarily Originate from the Mammary Gland. In Proceedings of Combined Biological Sciences Meeting, Perth, Australia, 28 August 2015.

46. Alsaweed, M.; Tat-Lai, C.; Hartmann, P.E.; Geddes, D.T.; Kakulas, F. Human milk miRNAs primarily originate from the mammary gland resulting in unique miRNA profiles of fractionated milk. Scientific Reports 2015, under review.

47. Alsaweed, M.; Hepworth, A.R.; Lefevre, C.; Hartmann, P.E.; Geddes, D.T.; Hassiotou, F. Human milk microRNA and total RNA differ depending on milk fractionation. J. Cell Biochem. 2015, doi:10.1002/jcb.25207.

48. Kosaka, N.; Izumi, H.; Sekine, K.; Ochiya, T. microRNA as a new immune-regulatory agent in breast milk. Silence 2010, doi:10.1186/1758-907X-1-7.

49. Li, Z.; Liu, H.; Jin, X.; Lo, L.; Liu, J. Expression profiles of microRNAs from lactating and non-lactating bovine mammary glands and identification of miRNA related to lactation. BMC Genomics 2012, doi:10.1186/1471-2164-13-731.

50. Avril-Sassen, S.; Goldstein, L.D.; Stingl, J.; Blenkiron, C.; Le Quesne, J.; Spiteri, I.; Karagavriilidou, K.; Watson, C.J.; Tavare, S.; Miska, E.A.; et al. Characterisation of microRNA expression in post-natal mouse mammary gland development. BMC Genomics 2009, doi:10.1186/1471-2164-10-548. 
51. Gu, Y.; Li, M.; Wang, T.; Liang, Y.; Zhong, Z.; Wang, X.; Zhou, Q.; Chen, L.; Lang, Q.; He, Z.; et al. Lactation-related microRNA expression profiles of porcine breast milk exosomes. PLoS ONE 2012, doi:10.1371/journal.pone.0043691.

52. Chen, X.; Gao, C.; Li, H.; Huang, L.; Sun, Q.; Dong, Y.; Tian, C.; Gao, S.; Dong, H.; Guan, D.; et al. Identification and characterization of microRNAs in raw milk during different periods of lactation, commercial fluid, and powdered milk products. Cell Res. 2010, 20, 1128-1137.

53. Hata, T.; Murakami, K.; Nakatani, H.; Yamamoto, Y.; Matsuda, T.; Aoki, N. Isolation of bovine milk-derived microvesicles carrying mRNAs and microRNAs. Biochem. Biophys. Res. Commun. 2010, 396, 528-533.

54. Izumi, H.; Kosaka, N.; Shimizu, T.; Sekine, K.; Ochiya, T.; Takase, M. Bovine milk contains microRNA and messenger RNA that are stable under degradative conditions. J. Dairy Sci. 2012, 95, 4831-4841.

55. Chen, T.; Xi, Q.Y.; Ye, R.S.; Cheng, X.; Qi, Q.E.; Wang, S.B.; Shu, G.; Wang, L.N.; Zhu, X.T.; Jiang, Q.Y.; et al. Exploration of microRNAs in porcine milk exosomes. BMC Genomics 2014, 15, doi:10.1186/1471-2164-15-100.

56. Izumi, H.; Kosaka, N.; Shimizu, T.; Sekine, K.; Ochiya, T.; Takase, M. Time-dependent expression profiles of microRNAs and mRNAs in rat milk whey. PLoS ONE 2014, doi:10.1371/journal.pone.0088843.

57. Modepalli, V.; Kumar, A.; Hinds, L.A.; Sharp, J.A.; Nicholas, K.R.; Lefevre, C. Differential temporal expression of milk miRNA during the lactation cycle of the marsupial tammar wallaby (Macropus eugenii). BMC Genomics 2014, doi:10.1186/1471-2164-15-1012.

58. Hassiotou, F.; Geddes, D.T.; Hartmann, P.E. Cells in human milk: State of the science. J. Hum. Lact. 2013, 29, 171-182.

59. Molinari, C.E.; Casadio, Y.S.; Hartmann, B.T.; Arthur, P.G.; Hartmann, P.E. Longitudinal analysis of protein glycosylation and beta-casein phosphorylation in term and preterm human milk during the first 2 months of lactation. Br. J. Nutr. 2013, 110, 105-115.

60. Mitoulas, L.R.; Kent, J.C.; Cox, D.B.; Owens, R.A.; Sherriff, J.L.; Hartmann, P.E. Variation in fat, lactose and protein in human milk over $24 \mathrm{~h}$ and throughout the first year of lactation. Br. J. Nutr. 2002, 88, 29-37.

61. Hassiotou, F.; Hepworth, A.R.; Williams, T.M.; Twigger, A.J.; Perrella, S.; Lai, C.T.; Filgueira, L.; Geddes, D.T.; Hartmann, P.E. Breastmilk cell and fat contents respond similarly to removal of breastmilk by the infant. PLoS ONE 2013, doi:10.1371/journal.pone.0078232.

62. Hassiotou, F.; Hepworth, A.R.; Metzger, P.; Tat Lai, C.; Trengove, N.; Hartmann, P.E.; Filgueira, L. Maternal and infant infections stimulate a rapid leukocyte response in breastmilk. Clin. Transl. Immunol. 2013, doi:10.1038/cti.2013.1.

63. Powe, C.E.; Knott, C.D.; Conklin-Brittain, N. Infant sex predicts breast milk energy content. Am. J. Hum. Biol. 2010, 22, 50-54.

64. Bachour, P.; Yafawi, R.; Jaber, F.; Choueiri, E.; Abdel-Razzak, Z. Effects of smoking, mother's age, body mass index, and parity number on lipid, protein, and secretory immunoglobulin a concentrations of human milk. Breastfeed. Med. 2012, 7, 179-188.

65. Bauer, J.; Gerss, J. Longitudinal analysis of macronutrients and minerals in human milk produced by mothers of preterm infants. Clin. Nutr. 2011, 30, 215-220. 
66. Zhang, M.W.; Jin, M.J.; Yu, Y.X.; Zhang, S.C.; Liu, B.; Jiang, X.; Pan, Y.F.; Li, Q.I.; Ma, S.Y.; Chen, K. Associations of lifestyle-related factors, hsa-miR-149 and hsa-miR-605 gene polymorphisms with gastrointestinal cancer risk. Mol. Carcinog. 2012, doi:10.1002/mc.20863.

67. Makrides, M.; Neumann, M.A.; Gibson, R.A. Effect of maternal docosahexaenoic acid (DHA) supplementation on breast milk composition. Eur. J. Clin. Nutr. 1996, 50, 352-357.

68. Melnik, B.C.; John, S.M.; Schmitz, G. Milk consumption during pregnancy increases birth weight, a risk factor for the development of diseases of civilization. J. Transl. Med. 2015, doi:10.1186/s12967014-0377-9.

69. Jiang, H.; Wu, W.; Zhang, M.; Li, J.; Peng, Y.; Miao, T.T.; Zhu, H.; Xu, G. Aberrant upregulation of miR-21 in placental tissues of macrosomia. J. Perinatol. 2014, 34, 658-663.

70. Hassiotou, F.; Geddes, D.T. Immune cell-mediated protection of the mammary gland and the infant during breastfeeding. Adv. Nutr. 2015, 6, 267-275.

71. Lawless, N.; Reinhardt, T.A.; Bryan, K.; Baker, M.; Pesch, B.; Zimmerman, D.; Zuelke, K.; Sonstegard, T.; O’Farrelly, C.; Lippolis, J.D.; et al. MicroRNA regulation of bovine monocyte inflammatory and metabolic networks in an in vivo infection model. G3 (Bethesda) 2014, 4, 957-971.

72. Sourvinou, I.S.; Markou, A.; Lianidou, E.S. Quantification of circulating miRNAs in plasma: Effect of preanalytical and analytical parameters on their isolation and stability. J. Mol. Diagn. 2013, 15, 827-834.

73. Wang, M.; Moisa, S.; Khan, M.J.; Wang, J.; Bu, D.; Loor, J.J. MicroRNA expression patterns in the bovine mammary gland are affected by stage of lactation. J. Dairy Sci. 2012, 95, 6529-6535.

74. Bian, Y.; Lei, Y.; Wang, C.; Wang, J.; Wang, L.; Liu, L.; Liu, L.; Gao, X.; Li, Q. Epigenetic regulation of miR-29s affects the lactation activity of dairy cow mammary epithelial cells. J. Cell. Physiol. 2015, 230, 2152-2163.

75. Dickinson, B.; Zhang, Y.; Petrick, J.S.; Heck, G.; Ivashuta, S.; Marshall, W.S. Lack of detectable oral bioavailability of plant microRNAs after feeding in mice. Nat. Biotechnol. 2013, 31, 965-967.

76. Mu, J.; Zhuang, X.; Wang, Q.; Jiang, H.; Deng, Z.B.; Wang, B.; Zhang, L.; Kakar, S.; Jun, Y.; Miller, D.; et al. Interspecies communication between plant and mouse gut host cells through edible plant derived exosome-like nanoparticles. Mol. Nutr. Food Res. 2014, 58, 1561-1573.

77. Garcia-Segura, L.; Perez-Andrade, M.; Miranda-Rios, J. The emerging role of MicroRNAs in the regulation of gene expression by nutrients. J. Nutrigenet. Nutrigenomics 2013, 6, 16-31.

78. Tian, T.; Wang, Y.; Wang, H.; Zhu, Z.; Xiao, Z. Visualizing of the cellular uptake and intracellular trafficking of exosomes by live-cell microscopy. J. Cell Biochem. 2010, 111, 488-496.

79. Tian, T.; Zhu, Y.L.; Hu, F.H.; Wang, Y.Y.; Huang, N.P.; Xiao, Z.D. Dynamics of exosome internalization and trafficking. J. Cell. Physiol. 2013, 228, 1487-1495.

80. Tian, T.; Zhu, Y.L.; Zhou, Y.Y.; Liang, G.F.; Wang, Y.Y.; Hu, F.H.; Xiao, Z.D. Exosome uptake through clathrin-mediated endocytosis and macropinocytosis and mediating miR-21 delivery. J. Biol. Chem. 2014, 289, 22258-22267.

81. Arntz, O.J.; Pieters, B.C.; Oliveira, M.C.; Broeren, M.G.; Bennink, M.B.; de Vries, M.; van Lent, P.L.; Koenders, M.I.; van den Berg, W.B.; et al. Oral administration of bovine milk derived extracellular vesicles attenuates arthritis in two mouse models. Mol. Nutr. Food Res. 2015, 59, 1701-1712. 
82. Hassiotou, F.; Mobley, A.; Geddes, D.T.; Hartmann, P.E.; Wilkie, T.M. Breastmilk Imparts the Mother's Stem Cells to the Infant; Experimental Biology: Boston, MA, USA, 2015.

83. Hassiotou, F.; Mobley, A.; Ocal, O.; Filgueira, L.; Geddes, D.T.; Hartmann, P.E.; Wilkie, T.M. Breastmilk Stem Cell Transfer from the Mother to Neonatal Organs: A Route of Migration and Integration; International Society for Research in Human Milk and Lactation: Charleston, SC, USA, 2014.

84. Sun, Q.; Chen, X.; Yu, J.; Zen, K.; Zhang, C.Y.; Li, L. Immune modulatory function of abundant immune-related microRNAs in microvesicles from bovine colostrum. Protein Cell 2013, 4, 197-210.

85. Ji, L.; Chen, X. Regulation of small RNA stability: Methylation and beyond. Cell Res. 2012, 22, 624-636.

86. Chen, X.; Ba, Y.; Ma, L.; Cai, X.; Yin, Y.; Wang, K.; Guo, J.; Zhang, Y.; Chen, J.; Guo, X.; et al. Characterization of microRNAs in serum: A novel class of biomarkers for diagnosis of cancer and other diseases. Cell Res. 2008, 18, 997-1006.

87. Bai, W.L.; Yin, R.H.; Yang, R.J.; Khan, W.A.; Ma, Z.J.; Zhao, S.J.; Jiang, W.Q.; Wang, Z.Y.; Zhu, Y.B.; Luo, G.B.; et al. Technical note: Identification of suitable normalizers for microRNA expression analysis in milk somatic cells of the yak (Bos grunniens). J. Dairy Sci. 2013, 96, 4529-4534.

88. Mitchell, P.S.; Parkin, R.K.; Kroh, E.M.; Fritz, B.R.; Wyman, S.K.; Pogosova-Agadjanyan, E.L.; Peterson, A.; Noteboom, J.; O’Briant, K.C.; Allen, A.; et al. Circulating microRNAs as stable blood-based markers for cancer detection. Proc. Natl. Acad. Sci. USA 2008, 105, 10513-10518.

89. Gilad, S.; Meiri, E.; Yogev, Y.; Benjamin, S.; Lebanony, D.; Yerushalmi, N.; Benjamin, H.; Kushnir, M.; Cholakh, H.; Melamed, N.; et al. Serum microRNAs are promising novel biomarkers. PLOS ONE 2008, doi:10.1371/journal.pone.0003148.

90. Fallingborg, J. Intraluminal $\mathrm{pH}$ of the human gastrointestinal tract. Dan. Med. Bull. 1999, 46, 183-196.

91. Title, A.C.; Denzler, R.; Stoffel, M. Uptake and function studies of maternal milk-derived microRNAs. J. Biol. Chem. 2015, doi:10.1074/jbc.M115.676734.

92. Bar-Sagi, D.; Fernandez, A.; Feramisco, J.R. Regulation of membrane turnover by ras proteins. Biosci. Rep. 1987, 7, 427-434.

93. Salunkhe, V.A.; Esguerra, J.L.; Ofori, J.K.; Mollet, I.G.; Braun, M.; Stoffel, M.; Wendt, A.; Eliasson, L. Modulation of microRNA-375 expression alters voltage-gated $\mathrm{Na}(+)$ channel properties and exocytosis in insulin-secreting cells. Acta Physiol. (Oxf.) 2015, 213, 882-892.

94. Yang, J.; Farmer, L.M.; Agyekum, A.A.; Hirschi, K.D. Detection of dietary plant-based small RNAs in animals. Cell Res. 2015, 25, 517-520.

95. Pothof, J.; Verkaik, N.S.; van, I.W.; Wiemer, E.A.; Ta, V.T.; van der Horst, G.T.; Jaspers, N.G.; van Gent, D.C.; Hoeijmakers, J.H.; Persengiev, S.P. MicroRNA-mediated gene silencing modulates the UV-induced DNA-damage response. EMBO J. 2009, 28, 2090-2099.

96. Kagias, K.; Podolska, A.; Pocock, R. Reliable reference miRNAs for quantitative gene expression analysis of stress responses in Caenorhabditis elegans. BMC Genomics 2014, doi:10.1186/14712164-15-222. 
97. Kraemer, A.; Chen, I.P.; Henning, S.; Faust, A.; Volkmer, B.; Atkinson, M.J.; Moertl, S.; Greinert, R. UVA and UVB irradiation differentially regulate microRNA expression in human primary keratinocytes. PLOS ONE 2013, doi:10.1371/journal.pone.0083392.

98. Syed, D.N.; Khan, M.I.; Shabbir, M.; Mukhtar, H. MicroRNAs in skin response to UV radiation. Curr. Drug Targets 2013, 14, 1128-1134.

99. Grignol, V.; Fairchild, E.T.; Zimmerer, J.M.; Lesinski, G.B.; Walker, M.J.; Magro, C.M.; Kacher, J.E.; Karpa, V.I.; Clark, J.; Nuovo, G.; et al. MiR-21 and miR-155 are associated with mitotic activity and lesion depth of borderline melanocytic lesions. Br. J. Cancer 2011, 105, 1023-1029.

100. Lindsay, M.A. microRNAs and the immune response. Trends Immunol 2008, 29, 343-351.

101. Lu, L.F.; Liston, A. MicroRNA in the immune system, microRNA as an immune system. Immunology 2009, 127, 291-298.

102. Pauley, K.M.; Cha, S.; Chan, E.K. MicroRNA in autoimmunity and autoimmune diseases. J. Autoimmun. 2009, 32, 189-194.

103. Lu, T.X.; Munitz, A.; Rothenberg, M.E. MicroRNA-21 is up-regulated in allergic airway inflammation and regulates IL-12p35 expression. J. Immunol. 2009, 182, 4994-5002.

104. Oddy, W.H. The long-term effects of breastfeeding on asthma and atopic disease. Adv. Exp. Med. Biol. 2009, 639, 237-2351.

105. Chen, C.Z.; Li, L.; Lodish, H.F.; Bartel, D.P. MicroRNAs modulate hematopoietic lineage differentiation. Science 2004, 303, 83-86.

106. Vigorito, E.; Perks, K.L.; Abreu-Goodger, C.; Bunting, S.; Xiang, Z.; Kohlhaas, S.; Das, P.P.; Miska, E.A.; Rodriguez, A.; Bradley, A.; et al. microRNA-155 regulates the generation of immunoglobulin class-switched plasma cells. Immunity 2007, 27, 847-859.

107. Li, Q.J.; Chau, J.; Ebert, P.J.; Sylvester, G.; Min, H.; Liu, G.; Braich, R.; Manoharan, M.; Soutschek, J.; Skare, P.; et al. miR-181a is an intrinsic modulator of T cell sensitivity and selection. Cell 2007, 129, 147-161.

108. De Yebenes, V.G.; Belver, L.; Pisano, D.G.; Gonzalez, S.; Villasante, A.; Croce, C.; He, L.; Ramiro, A.R. miR-181b negatively regulates activation-induced cytidine deaminase in B cells. J. Exp. Med. 2008, 205, 2199-2206.

109. Iliopoulos, D.; Jaeger, S.A.; Hirsch, H.A.; Bulyk, M.L.; Struhl, K. STAT3 activation of miR-21 and miR-181b-1 via PTEN and CYLD are part of the epigenetic switch linking inflammation to cancer. Mol. Cell 2010, 39, 493-506.

110. Quinn, S.R.; Mangan, N.E.; Caffrey, B.E.; Gantier, M.P.; Williams, B.R.; Hertzog, P.J.; McCoy, C.E.; O'Neill, L.A. The role of Ets2 transcription factor in the induction of microRNA-155 (miR-155) by lipopolysaccharide and its targeting by interleukin-10. J. Biol. Chem. 2014, 289, 4316-4325.

111. Tili, E.; Michaille, J.J.; Cimino, A.; Costinean, S.; Dumitru, C.D.; Adair, B.; Fabbri, M.; Alder, H.; Liu, C.G.; Calin, G.A.; et al. Modulation of miR-155 and miR-125b levels following lipopolysaccharide/TNF-alpha stimulation and their possible roles in regulating the response to endotoxin shock. J. Immunol. 2007, 179, 5082-5089.

112. Fontana, L.; Pelosi, E.; Greco, P.; Racanicchi, S.; Testa, U.; Liuzzi, F.; Croce, C.M.; Brunetti, E.; Grignani, F.; Peschle, C. MicroRNAs 17-5p-20a-106a control monocytopoiesis through AML1 targeting and M-CSF receptor upregulation. Nat. Cell Biol. 2007, 9, 775-787. 
113. Admyre, C.; Johansson, S.M.; Qazi, K.R.; Filen, J.J.; Lahesmaa, R.; Norman, M.; Neve, E.P.; Scheynius, A.; Gabrielsson, S. Exosomes with immune modulatory features are present in human breast milk. J. Immunol. 2007, 179, 1969-1978,

114. Tanaka, M.; Oikawa, K.; Takanashi, M.; Kudo, M.; Ohyashiki, J.; Ohyashiki, K.; Kuroda, M. Down-regulation of miR-92 in human plasma is a novel marker for acute leukemia patients. PLoS ONE 2009, doi:10.1371/journal.pone.0005532.

115. Ohyashiki, K.; Umezu, T.; Yoshizawa, S.; Ito, Y.; Ohyashiki, M.; Kawashima, H.; Tanaka, M.; Kuroda, M.; Ohyashiki, J.H. Clinical impact of down-regulated plasma miR-92a levels in non-Hodgkin's lymphoma. PLOS ONE 2011, doi:10.1371/journal.pone.0016408.

116. Taganov, K.D.; Boldin, M.P.; Chang, K.J.; Baltimore, D. NF-kappaB-dependent induction of microRNA miR-146, an inhibitor targeted to signaling proteins of innate immune responses. Proc. Natl. Acad. Sci. USA 2006, 103, 12481-12486.

117. Perry, M.M.; Moschos, S.A.; Williams, A.E.; Shepherd, N.J.; Larner-Svensson, H.M.; Lindsay, M.A. Rapid changes in microRNA-146a expression negatively regulate the IL-1beta-induced inflammatory response in human lung alveolar epithelial cells. J. Immunol. 2008, 180, 5689-5698.

118. Fukao, T.; Fukuda, Y.; Kiga, K.; Sharif, J.; Hino, K.; Enomoto, Y.; Kawamura, A.; Nakamura, K.; Takeuchi, T.; Tanabe, M. An evolutionarily conserved mechanism for microRNA-223 expression revealed by microRNA gene profiling. Cell 2007, 129, 617-631.

119. Johnnidis, J.B.; Harris, M.H.; Wheeler, R.T.; Stehling-Sun, S.; Lam, M.H.; Kirak, O.; Brummelkamp, T.R.; Fleming, M.D.; Camargo, F.D. Regulation of progenitor cell proliferation and granulocyte function by microRNA-223. Nature 2008, 451, 1125-1129.

120. Fazi, F.; Rosa, A.; Fatica, A.; Gelmetti, V.; de Marchis, M.L.; Nervi, C.; Bozzoni, I. A minicircuitry comprised of microRNA-223 and transcription factors NFI-A and C/EBPalpha regulates human granulopoiesis. Cell 2005, 123, 819-831.

121. Zhou, B.; Wang, S.; Mayr, C.; Bartel, D.P.; Lodish, H.F. miR-150, a microRNA expressed in mature B and T cells, blocks early B cell development when expressed prematurely. Proc. Natl. Acad. Sci. USA 2007, 104, 7080-7085.

122. Xiao, C.; Calado, D.P.; Galler, G.; Thai, T.H.; Patterson, H.C.; Wang, J.; Rajewsky, N.; Bender, T.P.; Rajewsky, K. MiR-150 controls B cell differentiation by targeting the transcription factor c-Myb. Cell 2007, 131, 146-159.

123. Gaziel-Sovran, A.; Segura, M.F.; Di Micco, R.; Collins, M.K.; Hanniford, D.; Vega-Saenz de Miera, E.; Rakus, J.F.; Dankert, J.F.; Shang, S.; Kerbel, R.S.; et al. miR-30b/30d regulation of GalNAc transferases enhances invasion and immunosuppression during metastasis. Cancer Cell 2011, 20, 104-118.

124. Stittrich, A.B.; Haftmann, C.; Sgouroudis, E.; Kuhl, A.A.; Hegazy, A.N.; Panse, I.; Riedel, R.; Flossdorf, M.; Dong, J.; Fuhrmann, F.; et al. The microRNA miR-182 is induced by IL-2 and promotes clonal expansion of activated helper T lymphocytes. Nat. Immunol. 2010, 11, 1057-1062.

125. Navarro, A.; Gaya, A.; Martinez, A.; Urbano-Ispizua, A.; Pons, A.; Balague, O.; Gel, B.; Abrisqueta, P.; Lopez-Guillermo, A.; Artells, R.; et al. MicroRNA expression profiling in classic Hodgkin lymphoma. Blood 2008, 111, 2825-2832. 
126. Ma, F.; Xu, S.; Liu, X.; Zhang, Q.; Xu, X.; Liu, M.; Hua, M.; Li, N.; Yao, H.; Cao, X. The microRNA miR-29 controls innate and adaptive immune responses to intracellular bacterial infection by targeting interferon-gamma. Nat. Immunol. 2011, 12, 861-869.

127. Pekarsky, Y.; Santanam, U.; Cimmino, A.; Palamarchuk, A.; Efanov, A.; Maximov, V.; Volinia, S.; Alder, H.; Liu, C.G.; Rassenti, L.; et al. Tcll expression in chronic lymphocytic leukemia is regulated by miR-29 and miR-181. Cancer Res. 2006, 66, 11590-11593.

128. Fulci, V.; Chiaretti, S.; Goldoni, M.; Azzalin, G.; Carucci, N.; Tavolaro, S.; Castellano, L.; Magrelli, A.; Citarella, F.; Messina, M.; et al. Quantitative technologies establish a novel microRNA profile of chronic lymphocytic leukemia. Blood 2007, 109, 4944-4951.

129. Calin, G.A.; Dumitru, C.D.; Shimizu, M.; Bichi, R.; Zupo, S.; Noch, E.; Aldler, H.; Rattan, S.; Keating, M.; Rai, K.; et al. Frequent deletions and down-regulation of micro- RNA genes miR15 and miR16 at 13q14 in chronic lymphocytic leukemia. Proc. Natl. Acad. Sci. USA 2002, 99, 15524-15529.

130. Pauley, K.M.; Satoh, M.; Chan, A.L.; Bubb, M.R.; Reeves, W.H.; Chan, E.K. Upregulated miR-146a expression in peripheral blood mononuclear cells from rheumatoid arthritis patients. Arthritis Res. Ther. 2008, doi:10.1186/ar2493.

131. Lawrie, C.H.; Soneji, S.; Marafioti, T.; Cooper, C.D.; Palazzo, S.; Paterson, J.C.; Cattan, H.; Enver, T.; Mager, R.; Boultwood, J.; et al. MicroRNA expression distinguishes between germinal center B cell-like and activated B cell-like subtypes of diffuse large B cell lymphoma. Int. J. Cancer 2007, 121, 1156-1161.

132. Koralov, S.B.; Muljo, S.A.; Galler, G.R.; Krek, A.; Chakraborty, T.; Kanellopoulou, C.; Jensen, K.; Cobb, B.S.; Merkenschlager, M.; Rajewsky, N.; et al. Dicer ablation affects antibody diversity and cell survival in the B lymphocyte lineage. Cell 2008, 132, 860-874.

133. Mendell, J.T. miRiad roles for the miR-17-92 cluster in development and disease. Cell 2008, 133, $217-222$.

134. Hassiotou, F.; Beltran, A.; Chetwynd, E.; Stuebe, A.M.; Twigger, A.J.; Metzger, P.; Trengove, N.; Lai, C.T.; Filgueira, L.; Blancafort, P.; et al. Breastmilk is a novel source of stem cells with multilineage differentiation potential. Stem Cells 2012, 30, 2164-2174.

135. Hassiotou, F.; Hepworth, A.R.; Beltran, A.S.; Mathews, M.M.; Stuebe, A.M.; Hartmann, P.E.; Filgueira, L.; Blancafort, P. Expression of the pluripotency transcription Factor OCT4 in the normal and aberrant mammary gland. Front. Oncol. 2013, doi:10.3389/fonc.2013.00079.

136. Sonkoly, E.; Stahle, M.; Pivarcsi, A. MicroRNAs and immunity: Novel players in the regulation of normal immune function and inflammation. Semin. Cancer Biol. 2008, 18, 131-140.

137. Keller, M.A.; Gendreau-Reid, L.; Heiner, D.C.; Rodriguez, A.; Short, J.A. IgG4 in human colostrum and human milk: Continued local production or selective transport from serum. Acta Paediatr. Scand. 1988, 77, 24-29.

138. Peitersen, B.; Bohn, L.; Andersen, H. Quantitative determination of immunoglobulins, lysozyme, and certain electrolytes in breast milk during the entire period of lactation, during a 24-h period, and in milk from the individual mammary gland. Acta Paediatr. Scand. 1975, 64, 709-717.

139. Goldman, A.S.; Garza, C.; Nichols, B.L.; Goldblum, R.M. Immunologic factors in human milk during the first year of lactation. J. Pediatr. 1982, 100, 563-567. 
140. Xiao, C.; Rajewsky, K. MicroRNA control in the immune system: Basic principles. Cell 2009, 136, 26-36.

141. Meng, F.; Henson, R.; Wehbe-Janek, H.; Smith, H.; Ueno, Y.; Patel, T. The MicroRNA let-7a modulates interleukin-6-dependent STAT-3 survival signaling in malignant human cholangiocytes. J. Biol. Chem. 2007, 282, 8256-8264.

142. Sheedy, F.J.; Palsson-McDermott, E.; Hennessy, E.J.; Martin, C.; O’Leary, J.J.; Ruan, Q.; Johnson, D.S.; Chen, Y.; O’Neill, L.A. Negative regulation of TLR4 via targeting of the proinflammatory tumor suppressor PDCD4 by the microRNA miR-21. Nat. Immunol. 2010, 11, 141-147.

143. Manetti, R.; Parronchi, P.; Giudizi, M.G.; Piccinni, M.P.; Maggi, E.; Trinchieri, G.; Romagnani, S. Natural killer cell stimulatory factor (interleukin 12 [IL-12]) induces T helper type 1 (Th1)-specific immune responses and inhibits the development of IL-4-producing Th cells. J. Exp. Med. 1993, 177, 1199-1204.

144. Jennewein, C.; von Knethen, A.; Schmid, T.; Brune, B. MicroRNA-27b contributes to lipopolysaccharide-mediated peroxisome proliferator-activated receptor gamma (PPARgamma) mRNA destabilization. J. Biol. Chem. 2010, 285, 11846-11853.

145. Gu, Z.; Eleswarapu, S.; Jiang, H. Identification and characterization of microRNAs from the bovine adipose tissue and mammary gland. FEBS Lett. 2007, 581, 981-988.

146. Yu, D.; Tan, A.H.; Hu, X.; Athanasopoulos, V.; Simpson, N.; Silva, D.G.; Hutloff, A.; Giles, K.M.; Leedman, P.J.; Lam, K.P.; et al. Roquin represses autoimmunity by limiting inducible T-cell co-stimulator messenger RNA. Nature 2007, 450, 299-303.

147. Cobb, B.S.; Hertweck, A.; Smith, J.; O’Connor, E.; Graf, D.; Cook, T.; Smale, S.T.; Sakaguchi, S.; Livesey, F.J.; Fisher, A.G.; Merkenschlager, M. A role for Dicer in immune regulation. J. Exp. Med. 2006, 203, 2519-2527.

148. Thai, T.H.; Calado, D.P.; Casola, S.; Ansel, K.M.; Xiao, C.; Xue, Y.; Murphy, A.; Frendewey, D.; Valenzuela, D.; Kutok, J.L.; et al. Regulation of the germinal center response by microRNA-155. Science 2007, 316, 604-608.

149. Kuhn, A.R.; Schlauch, K.; Lao, R.; Halayko, A.J.; Gerthoffer, W.T.; Singer, C.A. MicroRNA expression in human airway smooth muscle cells: Role of miR-25 in regulation of airway smooth muscle phenotype. Am. J. Respir. Cell Mol. Biol. 2010, 42, 506-513.

150. Lei, B.X.; Liu, Z.H.; Li, Z.J.; Li, C.; Deng, Y.F. miR-21 induces cell proliferation and suppresses the chemosensitivity in glioblastoma cells via downregulation of FOXO1. Int. J. Clin. Exp. Med. 2014, 7, 2060-2066.

151. Song, W.; Wang, L.; Wang, L.; Li, Q. Interplay of miR-21 and FoxO1 modulates growth of pancreatic ductal adenocarcinoma. Tumour Biol. 2015, 36, 4741-4745.

152. Gregory, P.A.; Bert, A.G.; Paterson, E.L.; Barry, S.C.; Tsykin, A.; Farshid, G.; Vadas, M.A.; Khew-Goodall, Y.; Goodall, G.J. The miR-200 family and miR-205 regulate epithelial to mesenchymal transition by targeting ZEB1 and SIP1. Nat. Cell Biol. 2008, 10, 593-601.

153. Brabletz, T.; Jung, A.; Hlubek, F.; Lohberg, C.; Meiler, J.; Suchy, U.; Kirchner, T. Negative regulation of CD4 expression in T cells by the transcriptional repressor ZEB. Int. Immunol. 1999, 11, 1701-1708. 
154. Naeem, A.; Zhong, K.; Moisa, S.J.; Drackley, J.K.; Moyes, K.M.; Loor, J.J. Bioinformatics analysis of microRNA and putative target genes in bovine mammary tissue infected with Streptococcus uberis. J. Dairy Sci. 2012, 95, 6397-6408.

155. Vickers, K.C.; Remaley, A.T. Lipid-based carriers of microRNAs and intercellular communication. Curr. Opin. Lipidol. 2012, 23, 91-97.

156. Rayner, K.J.; Hennessy, E.J. Extracellular communication via microRNA: Lipid particles have a new message. J. Lipid Res. 2013, 54, 1174-1181.

157. Fernandez-Hernando, C.; Suarez, Y.; Rayner, K.J.; Moore, K.J. MicroRNAs in lipid metabolism. Curr. Opin. Lipidol. 2011, 22, 86-92.

158. Rayner, K.J.; Suarez, Y.; Davalos, A.; Parathath, S.; Fitzgerald, M.L.; Tamehiro, N.; Fisher, E.A.; Moore, K.J.; Fernandez-Hernando, C. MiR-33 contributes to the regulation of cholesterol homeostasis. Science 2010, 328, 1570-1573.

159. Najafi-Shoushtari, S.H.; Kristo, F.; Li, Y.; Shioda, T.; Cohen, D.E.; Gerszten, R.E.; Naar, A.M. MicroRNA-33 and the SREBP host genes cooperate to control cholesterol homeostasis. Science 2010, 328, 1566-1569.

160. Schmitz, G.; Langmann, T. Structure, function and regulation of the ABC1 gene product. Curr. Opin. Lipidol. 2001, 12, 129-140.

161. Yvan-Charvet, L.; Wang, N.; Tall, A.R. Role of HDL, ABCA1, and ABCG1 transporters in cholesterol efflux and immune responses. Arterioscler. Thromb. Vasc. Biol. 2010, 30, 139-143.

162. Chen, T.; Huang, Z.; Wang, L.; Wang, Y.; Wu, F.; Meng, S.; Wang, C. MicroRNA-125a-5p partly regulates the inflammatory response, lipid uptake, and ORP9 expression in oxLDL-stimulated monocyte/macrophages. Cardiovasc. Res. 2009, 83, 131-139.

163. Olkkonen, V.M.; Levine, T.P. Oxysterol binding proteins: In more than one place at one time? Biochem. Cell Biol. 2004, 82, 87-98.

164. Raychaudhuri, S.; Im, Y.J.; Hurley, J.H.; Prinz, W.A. Nonvesicular sterol movement from plasma membrane to ER requires oxysterol-binding protein-related proteins and phosphoinositides. J. Cell Biol. 2006, 173, 107-119.

165. Lin, X.; Luo, J.; Zhang, L.; Wang, W.; Gou, D. MiR-103 controls milk fat accumulation in goat (Capra hircus) mammary gland during lactation. PLOS ONE 2013, doi:10.1371/journal. pone.0079258.

166. Sun, L.; Xie, H.; Mori, M.A.; Alexander, R.; Yuan, B.; Hattangadi, S.M.; Liu, Q.; Kahn, C.R.; Lodish, H.F. Mir193b-365 is essential for brown fat differentiation. Nat. Cell Biol. 2011, 13, 958965.

167. Thery, C.; Zitvogel, L.; Amigorena, S. Exosomes: Composition, biogenesis and function. Nat. Rev. Immunol. 2002, 2, 569-579.

168. Subra, C.; Laulagnier, K.; Perret, B.; Record, M. Exosome lipidomics unravels lipid sorting at the level of multivesicular bodies. Biochimie 2007, 89, 205-212. 
169. Huber, J.; Vales, A.; Mitulovic, G.; Blumer, M.; Schmid, R.; Witztum, J.L.; Binder, B.R.; Leitinger, N. Oxidized membrane vesicles and blebs from apoptotic cells contain biologically active oxidized phospholipids that induce monocyte-endothelial interactions. Arterioscler. Thromb. Vasc. Biol. 2002, 22, 101-107.

170. Zhang, Y.; Liu, D.; Chen, X.; Li, J.; Li, L.; Bian, Z.; Sun, F.; Lu, J.; Yin, Y.; Cai, X.; et al. Secreted monocytic miR-150 enhances targeted endothelial cell migration. Mol. Cell 2010, 39, 133-144.

171. Kopecki, Z.; Luchetti, M.M.; Adams, D.H.; Strudwick, X.; Mantamadiotis, T.; Stoppacciaro, A.; Gabrielli, A.; Ramsay, R.G.; Cowin, A.J. Collagen loss and impaired wound healing is associated with c-Myb deficiency. J. Pathol. 2007, 211, 351-361.

172. Valadi, H.; Ekstrom, K.; Bossios, A.; Sjostrand, M.; Lee, J.J.; Lotvall, J.O. Exosome-mediated transfer of mRNAs and microRNAs is a novel mechanism of genetic exchange between cells. Nat. Cell Biol. 2007, 9, 654-659.

173. Liang, Y.; Ridzon, D.; Wong, L.; Chen, C. Characterization of microRNA expression profiles in normal human tissues. BMC Genomics 2007, doi:10.1186/1471-2164-8-166.

174. Wang, V.; Wu, W. MicroRNA-based therapeutics for cancer. BioDrugs 2009, 23, 15-23.

175. Bader, A.G.; Brown, D.; Winkler, M. The promise of microRNA replacement therapy. Cancer Res. 2010, 70, 7027-7030.

176. Duursma, A.M.; Kedde, M.; Schrier, M.; le Sage, C.; Agami, R. miR-148 targets human DNMT3b protein coding region. RNA 2008, 14, 872-877.

177. Gao, Y.; Schug, J.; McKenna, L.B.; Le Lay, J.; Kaestner, K.H.; Greenbaum, L.E. Tissue-specific regulation of mouse microRNA genes in endoderm-derived tissues. Nucleic Acids Res. 2011, 39, 454-463.

178. Sempere, L.F.; Freemantle, S.; Pitha-Rowe, I.; Moss, E.; Dmitrovsky, E.; Ambros, V. Expression profiling of mammalian microRNAs uncovers a subset of brain-expressed microRNAs with possible roles in murine and human neuronal differentiation. Genome Biol. 2004, doi:10.1186/gb2004-5-3-r13.

179. Szafranska, A.E.; Davison, T.S.; John, J.; Cannon, T.; Sipos, B.; Maghnouj, A.; Labourier, E.; Hahn, S.A. MicroRNA expression alterations are linked to tumorigenesis and non-neoplastic processes in pancreatic ductal adenocarcinoma. Oncogene 2007, 26, 4442-4452.

180. Masaki, S.; Ohtsuka, R.; Abe, Y.; Muta, K.; Umemura, T. Expression patterns of microRNAs 155 and 451 during normal human erythropoiesis. Biochem. Biophys. Res. Commun. 2007, 364, 509-514.

181. Wang, S.; Aurora, A.B.; Johnson, B.A.; Qi, X.; McAnally, J.; Hill, J.A.; Richardson, J.A.; Bassel-Duby, R.; Olson, E.N. The endothelial-specific microRNA miR-126 governs vascular integrity and angiogenesis. Dev. Cell 2008, 15, 261-271.

182. Zhu, H.; Fan, G.C. Extracellular/circulating microRNAs and their potential role in cardiovascular disease. Am. J. Cardiovasc. Dis. 2011, 1, 138-149.

183. Wang, K.; Zhang, S.; Marzolf, B.; Troisch, P.; Brightman, A.; Hu, Z.; Hood, L.E.; Galas, D.J. Circulating microRNAs, potential biomarkers for drug-induced liver injury. Proc. Natl. Acad. Sci. USA 2009, 106, 4402-4407. 
184. Neville, M.C.; Anderson, S.M.; McManaman, J.L.; Badger, T.M.; Bunik, M.; Contractor, N.; Crume, T.; Dabelea, D.; Donovan, S.M.; Forman, N.; et al. Lactation and neonatal nutrition: Defining and refining the critical questions. J. Mammary Gland Biol. Neoplasia 2012, 17, 167-188.

185. Baumgartner, S.; Martin, D.; Hagios, C.; Chiquet-Ehrismann, R. Tenm, a Drosophila gene related to tenascin, is a new pair-rule gene. EMBO J. 1994, 13, 3728-3740.

186. Oohashi, T.; Zhou, X.H.; Feng, K.; Richter, B.; Morgelin, M.; Perez, M.T.; Su, W.D.; Chiquet-Ehrismann, R.; Rauch, U.; Fassler, R. Mouse ten-m/Odz is a new family of dimeric type II transmembrane proteins expressed in many tissues. J. Cell Biol. 1999, 145, 563-577.

187. Zheng, L.; Michelson, Y.; Freger, V.; Avraham, Z.; Venken, K.J.; Bellen, H.J.; Justice, M.J.; Wides, R. Drosophila Ten-m and filamin affect motor neuron growth cone guidance. PLoS ONE 2011, doi:10.1371/journal.pone.0022956.

188. Chen, Y.; Siegel, F.; Kipschull, S.; Haas, B.; Frohlich, H.; Meister, G.; Pfeifer, A. miR-155 regulates differentiation of brown and beige adipocytes via a bistable circuit. Nat. Commun. 2013, doi:10.1038/ncomms2742.

189. He, A.; Zhu, L.; Gupta, N.; Chang, Y.; Fang, F. Overexpression of micro ribonucleic acid 29, highly up-regulated in diabetic rats, leads to insulin resistance in 3T3-L1 adipocytes. Mol. Endocrinol. 2007, 21, 2785-2794.

190. Dehwah, M.A.; Xu, A.; Huang, Q. MicroRNAs and type 2 diabetes/obesity. J. Genet. Genomics 2012, 39, 11-18.

191. Hassiotou, F.; Geddes, D.T. Programming of appetite control during breastfeeding as a preventative strategy against the obesity epidemic. J. Hum. Lact. 2014, 30, 136-142.

192. Van Kouwenhove, M.; Kedde, M.; Agami, R. MicroRNA regulation by RNA-binding proteins and its implications for cancer. Nat. Rev. Cancer 2011, 11, 644-656.

193. Calin, G.A.; Croce, C.M. MicroRNA signatures in human cancers. Nat. Rev. Cancer 2006, 6, 857-866.

194. Gaard, M.; Tretli, S.; Loken, E.B. Dietary fat and the risk of breast cancer: A prospective study of 25,892 Norwegian women. Int. J. Cancer 1995, 63, 13-17.

195. Qin, L.Q.; Xu, J.Y.; Tezuka, H.; Li, J.; Arita, J.; Hoshi, K.; Sato, A. Consumption of commercial whole and non-fat milk increases the incidence of 7,12-dimethylbenz(a)anthracene-induced mammary tumors in rats. Cancer Detect. Prev. 2007, 31, 339-343.

196. Allen, N.E.; Key, T.J.; Appleby, P.N.; Travis, R.C.; Roddam, A.W.; Tjonneland, A.; Johnsen, N.F.; Overvad, K.; Linseisen, J.; Rohrmann, S.; et al. Animal foods, protein, calcium and prostate cancer risk: The European Prospective Investigation into Cancer and Nutrition. Br. J. Cancer 2008, 98, 1574-1581.

197. Song, Y.; Chavarro, J.E.; Cao, Y.; Qiu, W.; Mucci, L.; Sesso, H.D.; Stampfer, M.J.; Giovannucci, E.; Pollak, M.; Liu, S.; et al. Whole milk intake is associated with prostate cancer-specific mortality among U.S. male physicians. J. Nutr. 2013, 143, 189-196.

198. Torfadottir, J.E.; Steingrimsdottir, L.; Mucci, L.; Aspelund, T.; Kasperzyk, J.L.; Olafsson, O.; Fall, K.; Tryggvadottir, L.; Harris, T.B.; Launer, L.; et al. Milk intake in early life and risk of advanced prostate cancer. Am. J. Epidemiol. 2012, 175, 144-153. 
199. Duarte-Salles, T.; Fedirko, V.; Stepien, M.; Trichopoulou, A.; Bamia, C.; Lagiou, P.; Lukanova, A.; Trepo, E.; Overvad, K.; Tjonneland, A.; et al. Dairy products and risk of hepatocellular carcinoma: The european prospective investigation into cancer and nutrition. Int. J. Cancer 2014, 135, 16621672.

200. Melnik, B.C. MiR-21: An environmental driver of malignant melanoma? J. Transl. Med. 2015, doi:10.1186/s12967-015-0570-5.

201. Meng, F.; Henson, R.; Wehbe-Janek, H.; Ghoshal, K.; Jacob, S.T.; Patel, T. MicroRNA-21 regulates expression of the PTEN tumor suppressor gene in human hepatocellular cancer. Gastroenterology 2007, 133, 647-658.

202. Olivieri, F.; Spazzafumo, L.; Santini, G.; Lazzarini, R.; Albertini, M.C.; Rippo, M.R.; Galeazzi, R.; Abbatecola, A.M.; Marcheselli, F.; Monti, D.; et al. Age-related differences in the expression of circulating microRNAs: miR-21 as a new circulating marker of inflammaging. Mech. Ageing Dev. 2012, 133, 675-685.

203. Melnik, B.C.; John, S.M.; Schmitz, G. Milk is not just food but most likely a genetic transfection system activating mTORC1 signaling for postnatal growth. Nutr. J. 2013, doi:10.1186/1475-2891-12-103.

204. Kim, Y.J.; Hwang, S.J.; Bae, Y.C.; Jung, J.S. MiR-21 regulates adipogenic differentiation through the modulation of TGF-beta signaling in mesenchymal stem cells derived from human adipose tissue. Stem Cells 2009, 27, 3093-3102.

205. Hammond, S.M. MicroRNAs as tumor suppressors. Nat. Genet. 2007, 39, 582-583.

206. Johnson, S.M.; Grosshans, H.; Shingara, J.; Byrom, M.; Jarvis, R.; Cheng, A.; Labourier, E.; Reinert, K.L.; Brown, D.; Slack, F.J. RAS is regulated by the let-7 microRNA family. Cell 2005, 120, 635-647.

207. Miller, E.M.; Aiello, M.O.; Fujita, M.; Hinde, K.; Milligan, L.; Quinn, E.A. Field and laboratory methods in human milk research. Am. J. Hum. Biol. 2013, 25, 1-11.

208. Hassiotou, F.; Hartmann, P.E. At the dawn of a new discovery: The potential of breast milk stem cells. Adv. Nutr. 2014, 5, 770-778.

209. Melnik, B.C. Milk-A Nutrient System of Mammalian Evolution Promoting mTORC1-Dependent Translation. Int. J. Mol. Sci. 2015, 16, 17048-17087.

210. Greer, F.R.; Sicherer, S.H.; Burks, A.W.; American Academy of Pediatrics. Effects of early nutritional interventions on the development of atopic disease in infants and children: The role of maternal dietary restriction, breastfeeding, timing of introduction of complementary foods, and hydrolyzed formulas. Pediatrics 2008, 121, 183-191.

211. Fein, S.B.; Falci, C.D. Infant formula preparation, handling, and related practices in the United States. J. Am. Diet. Assoc. 1999, 99, 1234-1240.

212. Cregan, M.D.; Fan, Y.; Appelbee, A.; Brown, M.L.; Klopcic, B.; Koppen, J.; Mitoulas, L.R.; Piper, K.M.; Choolani, M.A.; Chong, Y.S.; et al. Identification of nestin-positive putative mammary stem cells in human breastmilk. Cell Tissue Res. 2007, 329, 129-136.

213. Verduci, E.; Banderali, G.; Barberi, S.; Radaelli, G.; Lops, A.; Betti, F.; Riva, E.; Giovannini, M. Epigenetic effects of human breast milk. Nutrients 2014, 6, 1711-1724.

214. Bode, L.; McGuire, M.; Rodriguez, J.M.; Geddes, D.T.; Hassiotou, F.; Hartmann, P.E.; McGuire, M.K. It's alive: Microbes and cells in human milk and their potential benefits to mother and infant. Adv. Nutr. 2014, 5, 571-573. 
215. Food and Drug Administration, Department of Health \& Human Services. Current good manufacturing practices, quality control procedures, quality factors, notification requirements, and records and reports, for infant formula. Fed. Regist. 2014, 79, 33057-33072.

216. Gigli, I.; Maizon, D.O. microRNAs and the mammary gland: A new understanding of gene expression. Genet. Mol. Biol. 2013, 36, 465-474.

217. Melnik, B.C.; John, S.M.; Schmitz, G. Milk: An exosomal microRNA transmitter promoting thymic regulatory $\mathrm{T}$ cell maturation preventing the development of atopy? J. Transl. Med. 2014, doi:10.1186/1479-5876-12-43.

218. Xiao, J.; Zhu, X.; He, B.; Zhang, Y.; Kang, B.; Wang, Z.; Ni, X. MiR-204 regulates cardiomyocyte autophagy induced by ischemia-reperfusion through LC3-II. J. Biomed. Sci. 2011, 18, 35, doi:10.1186/1423-0127-18-35.

219. Blenkiron, C.; Miska, E.A. miRNAs in cancer: Approaches, aetiology, diagnostics and therapy. Hum. Mol. Genet. 2007, doi:10.1093/hmg/ddm056.

220. Heneghan, H.M.; Miller, N.; Lowery, A.J.; Sweeney, K.J.; Kerin, M.J. MicroRNAs as novel biomarkers for breast cancer. J. Oncol. 2009, doi:10.1155/2010/950201.

221. Heneghan, H.M.; Miller, N.; Lowery, A.J.; Sweeney, K.J.; Newell, J.; Kerin, M.J. Circulating microRNAs as novel minimally invasive biomarkers for breast cancer. Ann. Surg. 2010, 251, 499-505.

(C) 2015 by the authors; licensee MDPI, Basel, Switzerland. This article is an open access article distributed under the terms and conditions of the Creative Commons Attribution license (http://creativecommons.org/licenses/by/4.0/). 